OPEN ACCESS

Edited by:

Ignazio Piras,

Translational Genomics Research Institute (TGen), United States

Reviewed by:

Ahmed Nadeem,

King Saud University, Saudi Arabia

Yong Cheng,

Minzu University of China, China

*Correspondence:

Liming Shen

s/m@szu.edu.cn

Specialty section:

This article was submitted to

Autism,

a section of the journal

Frontiers in Psychiatry

Received: 12 November 2021 Accepted: 24 January 2022

Published: 01 March 2022

Citation:

Liu X, Lin J, Zhang H, Khan NU,

Zhang J, Tang $X$, Cao $X$ and Shen $L$ (2022) Oxidative Stress in Autism

Spectrum Disorder-Current Progress

of Mechanisms and Biomarkers.

Front. Psychiatry 13:813304.

doi: 10.3389/fpsyt.2022.813304

\section{Oxidative Stress in Autism Spectrum Disorder-Current Progress of Mechanisms and Biomarkers}

\author{
Xukun Liu ${ }^{1,2,3}$, Jing Lin ${ }^{1}$, Huajie Zhang ${ }^{1}$, Naseer Ullah Khan ${ }^{1}$, Jun Zhang ${ }^{1}$, Xiaoxiao Tang ${ }^{1}$, \\ Xueshan $\mathrm{Cao}^{1}$ and Liming Shen ${ }^{1,2,4 *}$ \\ ${ }^{1}$ College of Life Science and Oceanography, Shenzhen University, Shenzhen, China, ${ }^{2}$ Shenzhen-Hong Kong Institute of Brain \\ Science-Shenzhen Fundamental Research Institutions, Shenzhen, China, ${ }^{3}$ Shenzhen Key Laboratory of Marine \\ Biotechnology and Ecology, Shenzhen, China, ${ }^{4}$ Brain Disease and Big Data Research Institute, Shenzhen University, \\ Shenzhen, China
}

Autism spectrum disorder (ASD) is a type of neurodevelopmental disorder that has been diagnosed in an increasing number of children around the world. Existing data suggest that early diagnosis and intervention can improve ASD outcomes. However, the causes of ASD remain complex and unclear, and there are currently no clinical biomarkers for autism spectrum disorder. More mechanisms and biomarkers of autism have been found with the development of advanced technology such as mass spectrometry. Many recent studies have found a link between ASD and elevated oxidative stress, which may play a role in its development. ASD is caused by oxidative stress in several ways, including protein post-translational changes (e.g., carbonylation), abnormal metabolism (e.g., lipid peroxidation), and toxic buildup [e.g., reactive oxygen species (ROS)]. To detect elevated oxidative stress in ASD, various biomarkers have been developed and employed. This article summarizes recent studies about the mechanisms and biomarkers of oxidative stress. Potential biomarkers identified in this study could be used for early diagnosis and evaluation of ASD intervention, as well as to inform and target ASD pharmacological or nutritional treatment interventions.

Keywords: treatment, oxidative stress, early diagnosis, biomarker, autism spectrum disorder

\section{INTRODUCTION}

Autism spectrum disorder (ASD) is a type of neurodevelopmental disorder characterized by impaired social communication and interactions, as well as repetitive behavior and limited interests (1). Decades of research have shown that the prevalence of ASD has increased dramatically. According to the Centers for Disease Control and Prevention, one out of every 59 children in the United States is diagnosed with ASD among 8-year-olds in 2018, with boys being four times more likely to be diagnosed than girls (2). ASD's etiology is complex, and it may be due to the interaction of genetic and environmental factors $(3,4)$. Its development is also heavily influenced by genetic factors $(5,6)$. Pathogenesis is linked to metabolic disorders, gut microbiota, viral and bacterial infections, chemical influences on the mother's body during pregnancy, as well as neurological and immunological factors $(3,7-9)$.

There are no clinical biomarkers for ASD because the disorder's etiology and pathogenesis are unknown $(3,10)$. ASD is diagnosed based on an autism-specific history and clinical observation $(3,10,11)$. This could lead to a delay in diagnosis. Although early signs of ASD can be observed 
and diagnosed as early as 15-18 months of age, the average age of diagnosis is about 4.5 years, and it is not even possible to diagnose ASD before this age (3). Currently, there are no effective pharmaceutical treatments for ASD's fundamental symptoms (12). Early behavioral therapies, on the other hand, have been found to be beneficial in lowering disability and making a significant impact on the outcomes for children with ASD, but they are most effective when started early $(13,14)$. It has been suggested that interventions initiated before 3 years of age may have a stronger favorable impact than those initiated after the age of five (14). Thus, early diagnosis is essential for ASD, prompting researchers to look for ASD biomarkers. In addition to early diagnosis, reliable ASD biomarker groups are beneficial in clinical practice because they measure the risk of birth in "baby siblings" of children with ASD (15). It also reflects pathogenic processes, assesses treatment and intervention results, and identifies a physiologically homogeneous cohort of ASD patients (16). Moreover, it reveals unknown causes and offers a better knowledge of the disease's underlying pathophysiological processes (17).

However, ASD is a genetically diverse disorder. More than 1,000 genes have been linked to ASD, but none have been found to account for more than $1 \%$ of cases $(6,18)$. Meanwhile, intellectual disability, trouble coordinating movement, sleep difficulties, seizures, and gastrointestinal (GI) issues are also common comorbidities associated with ASD (19). Therefore, identifying biomarkers for ASD has been challenging. Despite this, the evidence suggests that immunological dysregulation, inflammation, oxidative stress, mitochondrial dysfunction, and excitotoxicity are key components in ASD pathogenesis $(3,10$, $20,21)$. The biomarker related to them have been detected in the blood and urine, and these abnormalities have also been observed in the brain of individuals with ASD, indicating that they could be used to reduce diagnostic heterogeneity and enhance treatment response prediction. So far, many studies have reported increased oxidative stress in individuals with ASD, including decreased enzymatic antioxidants, and increased DNA, lipid, and protein oxidation products both in the brain and peripheral circulation (22-28). Increased oxidative stress markers have been found in peripheral body fluids and have been linked to ASD severity (29).

This article reviews the current state of research on oxidative stress in ASDs, focusing on the mechanism of oxidative stress, biological analysis of oxidative stress biomarkers, and antioxidant-based therapy methods. The literature focused on the last 10 years and was collected from PubMed, Web of Science, and Google Scholar.

\section{OXIDATIVE STRESS AND ASD}

The concept of oxidative stress was initially introduced in 1985 with the publication of the book "Oxidative Stress" (30). Reduction-oxidation (redox) reaction is a type of indispensable reaction in the cellular physiological process of cells, during which ROS are generated. ROS is typically produced either intentionally (to kill invading pathogens or as intermediates in enzymatic reactions, etc.) or accidentally (via electron leakage from electron transport chains, metabolism of drugs, exposure to chemicals, pollutants, and radiation, etc.) during normal physiological processes of cells. The sources of ROS contain many enzymes. Nicotinamide adenine dinucleotide phosphate oxidase (NOX) isoforms are major sources for endogenous ROS, multifarious NOX isoforms are localized to various cellular membranes and involved in many physiological or pathological events $(31,32)$. Myeloperoxidase (MPO) is primarily located in immune cells and plays an important role in our immune system, which produces some ROS, particularly hypochlorous acid (HOCl) to kill invading pathogens (33). NO synthases (NOSs) are the most important $\mathrm{NO}$ source in both physiological and pathological conditions (34). Interestingly, low concentrations of NO generated by neuronal NOS or endothelial NOS have a physiological neuroprotective function and are involved in signaling pathway, while higher concentrations of $\mathrm{NO}$ synthesized by inducible NOS (iNOS) are neurotoxic $(35,36)$. Beside the sources of ROS mentioned above, there are also many ROS-generating enzymes include succinate dehydrogenase (SDH) (37), dihydroorotate dehydrogenase (DHOH) (38), mitochondrial glycerol-1-phosphate dehydrogenase (mGPDH) (39), cytochrome b5 reductase (40), monoamine oxidases (MAOs) (41), aconitase (ACO) (42), xanthine oxidoreductase (XOR) (43), alpha-Ketoglutarate dehydrogenase complex (KGDHC) (44), and so on. Some of these enzymes were shown to produce ROS at appreciable rates in studies with either isolated enzymes or mitochondria (45). Additionally, it should be noted that ROS is a general term but not some specific molecule (46-48). It contains a group of molecules that come from molecular oxygen, such as superoxide $\left(\mathrm{O}_{2}^{\bullet-}\right)$, hydrogen peroxide $\left(\mathrm{H}_{2} \mathrm{O}_{2}^{\bullet}\right)$, hydroxyl radical $\left(\mathrm{OH}^{\bullet-}\right)$, and peroxyl radical $\left(\mathrm{RO}_{2}^{\bullet-}\right)$, and the chemical reactivity of each ROS molecule is quite different $(46,47,49)$.

ROS are eliminated by the antioxidant defense of cells in normal physiological processes, and the body is in a state of physiological balance. This balance, however, will be disrupted if there is an increase in ROS production or a decrease in cell antioxidant capacity, resulting in oxidative stress $(46,47)$. When there is mild oxidative stress, a low level of ROS stimulates the cellular defense mechanism to produce a proper response to ROS, while ROS can also induce cell apoptosis as a signal molecule. This phenomenon is known as "eustress," and it is beneficial to the maintenance of cellular ROS defense and tissue renewal $(48,50,51)$. When cells are subjected to severe oxidative stress, ROS that is out of balance with antioxidant capacity damage biomolecules such as proteins, lipids, and DNA, as well as some biological structures such as bio-membrane structure. This is known as "distress."

As the energy factories of cells, mitochondria are the main sites for the generation of ROS, in which the electron transport chain (ETC) is a prime source for ROS (38). Both endogenous and exogenous oxidative stress can cause a deficit in mitochondrial ETC complexes, resulting in mitochondrial dysfunction. Dysfunctional mitochondria produce more ROS, which can further impair mitochondrial function. This is a vicious cycle in which more severe oxidative stress and mitochondrial dysfunction occur if ROS is not eliminated 
promptly due to decreased antioxidant capacity. Glutathione (GSH) has been shown in numerous studies to play an important role in mitochondrial ROS elimination $(24,26,52,53)$.

The antioxidant capacity of various cellular defense systems is based on enzymatic antioxidants such as superoxide dismutase (SOD), catalase (CAT) and glutathione peroxidase (GSH$\mathrm{Px}$ ), and non-enzymatic antioxidants such as ascorbic acid (vitamins C), uric acid, tocopherol (vitamins E), quinols, carotenoids, and polyphenols. The interaction between some common antioxidants and ROS has been shown in Figure 1 (54-65). It is worth noting that some enzymatic antioxidants have multiple isoforms, and the different isoforms have different functions, such as SOD (66), GSH-Px (67), etc. Furthermore, as a complement to defense systems, some repair systems, such as methionine sulfoxide reductases, disulfide reductases/isomerases, phospholipases, and DNA repair enzymes, will repair structures and biomolecules that have been damaged or modified by residual ROS. As a result, when cells are subjected to mild oxidative stress, these mechanisms can effectively protect them from oxidative damage (46-48). Although there are numerous mechanisms in cells to combat oxidative stress, numerous studies show that oxidative damage to biological structures and biomolecules continues to accumulate in cells in many related diseases, including ASD (46, 47, 68-72).

The human brain is the largest oxygen-consuming organ in the body. It only accounts for $2 \%$ of the body mass but consumes $20 \%$ of the oxygen. It has a high content of oxidizable polyunsaturated fatty acids as well as redox-active metals (copper and iron). As a result, the human brain is particularly vulnerable to oxidative stress $(47,73-75)$. Children are more vulnerable than adults to oxidative stress because of their naturally low glutathione levels from conception to infancy (72). In the brains of children with ASD, low levels of mitochondrial glutathione and mitochondrial dysfunction have been reported $(24,26,52,53)$. In particular, increased oxidative stress has been observed in the brains of children with ASD (24). Oxidative stress causes oxidative damage to lipids, proteins, and DNA in cells. It makes a variety of reversible and irreversible damages in ASD which mainly involves various post-translational modifications of proteins such as 3-nitrotyrosine (3NT) and protein carbonyl formation, abnormal metabolism such as lipid peroxidation, and accumulation of toxic such as ROS. The relationship between oxidative stress and ASD has recently been thoroughly reviewed (76). Many markers of oxidative stress, such as lipid peroxide (LOOH) (77), malondialdehyde (MDA) (78), a marker of oxidative DNA damage 8-hydroxy-2'-deoxyguanosine (8-OHdG) (24), protein carbonyl $(28,79)$, and 3-nitrotyrosine (3NT), are elevated in children with ASD. The increased oxidative stress markers have been observed to be correlated with ASD severity (29).

Furthermore, several studies have shown that oxidative stress causes an inflammatory response as an upstream component in the signaling cascade $(80,81)$. ASD patients have been shown to have systemic immunological abnormalities as well as an inflammatory response $(82,83)$. In fact, oxidative stress is often detected alongside inflammation in the brains of people with ASD, and some studies have demonstrated a link between the two in specific brain regions associated with ASD (24, 84, 85). Even though it is difficult to know whether the connection is unique to specific brain regions or not due to the limitations of the brain tissue sample, this has revealed more about the role of oxidative stress in the etiology of ASD. Other studies in peripheral blood cells have found evidence of inflammation and oxidative stress in a variety of cell types, including T cells $(86,87)$, B cells (88), monocytes $(89,90)$, neutrophils (90), and lymphocytes (91). In these studies, in vitro induction experiments were also used to demonstrate the link between inflammation and oxidative stress in peripheral cells. Peripheral cells may be useful in studying systemic neurochemical changes in ASD.

In general, oxidative stress is involved in the pathogenesis of ASD. As a result of the interaction of genetic and environmental factors, people with ASD have excessive ROS production, decreased antioxidant capacity, and mitochondrial dysfunction (55). All of these physiological abnormalities have the potential to cause oxidative stress $(55,92,93)$. And oxidative stress can cause epigenetic dysregulation $(55,93)$, neurodevelopment disorder (94), neuro-inflammation (95), cerebral injury $(55,92,95)$, and neuro-dysfunction $(55,92,95)$, which finally leads to ASD (94-96). Figure 2 depicts the potential mechanisms of oxidative stress in the pathogenesis of ASD.

\section{BIOMARKERS OF OXIDATIVE STRESS}

The studies of potential oxidative stress biomarkers for ASD in the past 10 years are shown in Table 1. It focuses on proteins and metabolites related to oxidative stress in peripheral body fluids such as blood, urine, and saliva. These potential biomarkers include enzymatic antioxidants, non-enzymatic antioxidants, proteins, and lipids damaged by oxidation $(28,29,97-140)$. It is critical to verify whether the changes reported in different research are consistent as a potential biomarker. Individual variances must be adapted by effective biomarkers, especially in the case of disease as heterogeneous. Most of these potential biomarker changes in ASD patients are consistent without dissenting reports. Here, we will focus on a few classic oxidative stress biomarkers related to ASD and introduce them according to their classification.

\section{Blood-Based Biomarker GSH, GSSG, and GSH/GSSG}

Genetic variations in glutathione-related pathways have been observed in ASD (141-144) and have been correlated to ASD behaviors in some studies $(145,146)$. GSH has been reported as a biomarker of ASD oxidative stress in numerous studies, as shown in Table 1. The levels of GSH in the blood of autistic patients have been reported to be variable. Some studies have found that GSH levels are elevated when compared to healthy controls, while other studies have found lower levels (101). However, a recent meta-analysis found that GSH and total glutathione (tGSH) levels in the blood are lower in people with ASD compared to controls (147).

GSH is an important antioxidant in the human body that protects against oxidative stress. It has the ability to detoxify cytotoxic molecules. Lower GSH levels were found to be 


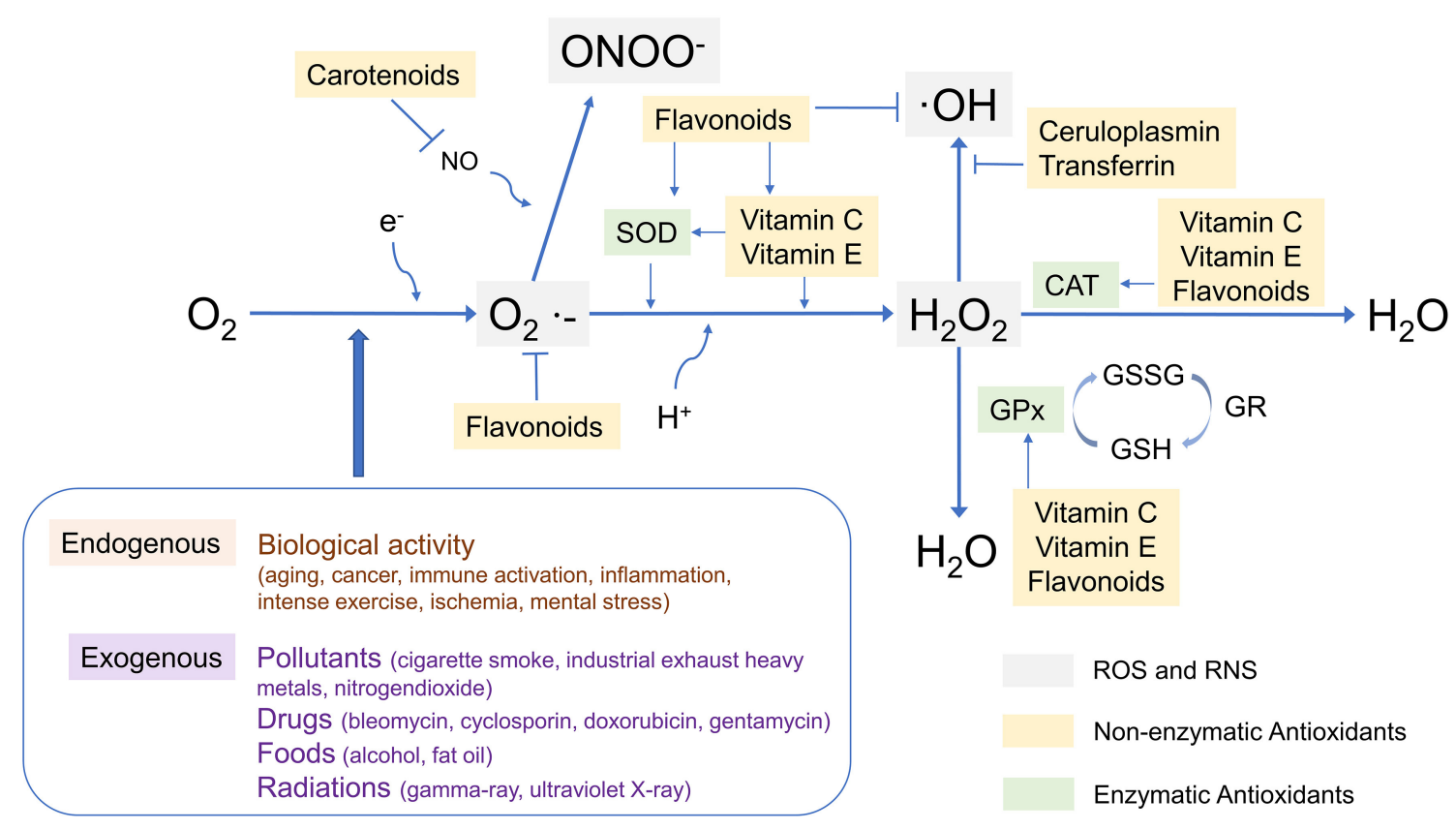

FIGURE 1 | The interaction between some common antioxidants and ROS. SOD, superoxide dismutase; CAT, catalase; GPX, glutathione peroxidase; O2.-, superoxide; $\cdot \mathrm{OH}$, hydroxyl radical; ONOO-, Peroxynitrite; GSSG, glutathione oxidized; GSH, glutathione; GR, gluathione reductase.

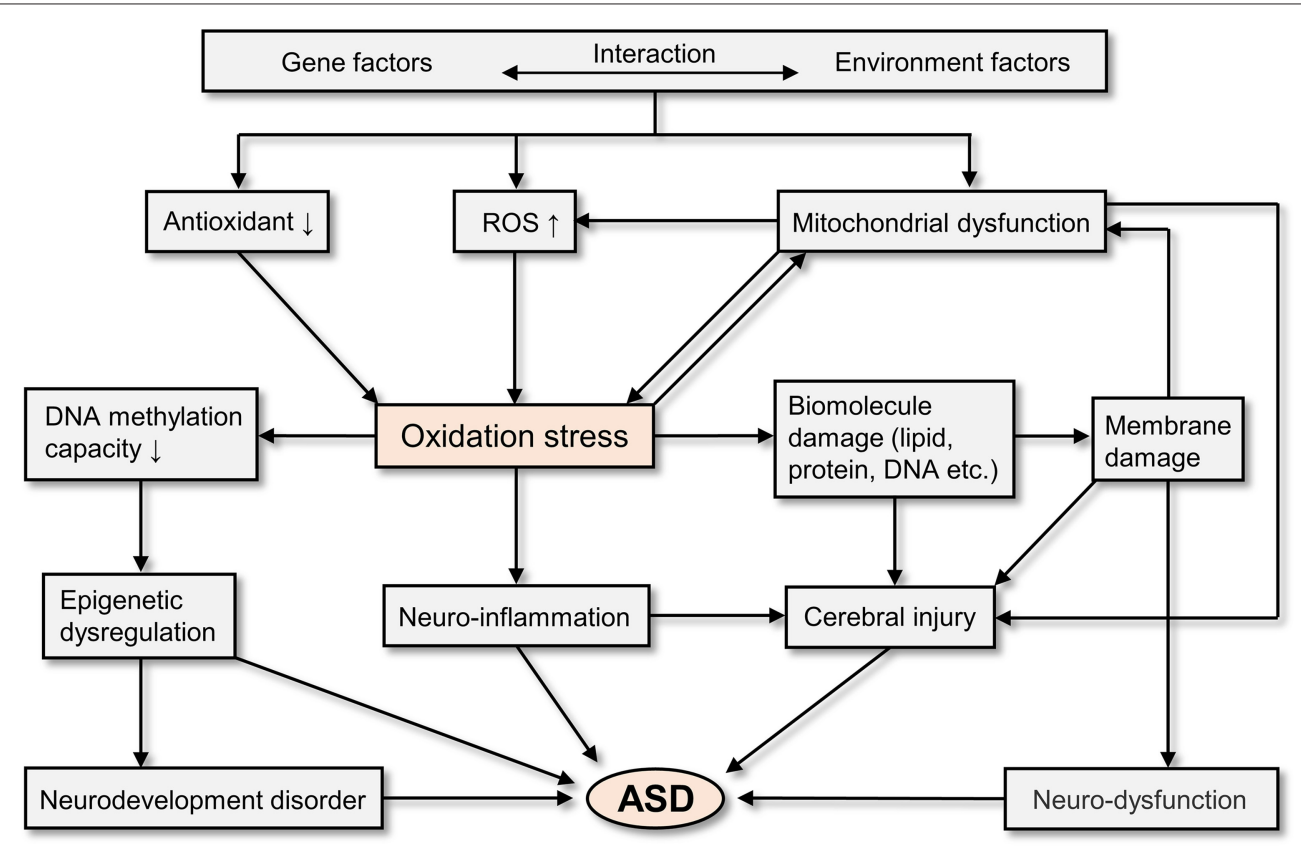

FIGURE 2 | The potential mechanisms of oxidative stress in the brain of ASD patients.

associated with the severity of ASD in a previous study (148). Toxic metals are one of the environmental factors that contribute to ASD. They can cause oxidative stress, which can lead to ASD $(4,149)$. In this case, it will expend a significant amount of GSH $(150,151)$. This may be one of the reasons for the disparities in the results of different studies. In general, as oxidative stress increases, it appears that GSH levels will decrease as consumption exceeds production. However, there is a compensation effect on the human body. In order to resist the increased oxidative stress, the production of GSH may be increased (152-154). Therefore, 
the diversity of GSH functions and individual differences are responsible for the difference in GSH levels in ASD patients. GSH, on the other hand, is known to be converted into oxidized glutathione (GSSG) by glutathione peroxidase and reduced back to GSH by glutathione reductase in the human body. The increased GSH consumption caused by oxidative stress will disrupt this dynamic equilibrium of GSH and GSSH (152-154). Therefore, many studies have detected not only the level of GSH in the sample but also the GSH/GSSG ratio. Interestingly, the rising GSH/GSSG ratio is a consistent result in all related studies $(101,103,105,114,121)$, indicating that it is a good indicator of oxidative stress in the human body. This is consistent with the findings of a meta-analysis of oxidative stress marker abnormalities in children with ASD (147). In this meta-analysis, GSSG was found to be increased in autistic children, while tGSH/GSSG was decreased (147).

Taken together, blood glutathione metabolism markers are one of the important ASD oxidative stress markers. In different studies, it usually demonstrated constant and high significant differences between ASD children and controls (147). Besides, a postmortem study showed that GSH and GSH/GSSG were significantly decreased in the brains of ASD patients relative to controls (24). These glutathione metabolism markers may show parallel changes between the central and peripheral nervous systems in ASD.

\section{Homocysteine and Vitamin B6, B9, and B12}

Hcy is a non-protein amino acid derived from the methionine cycle that is required for activated methyl transfer and the transsulfuration pathway (155). Previous research on Hcy levels in the blood of autistic children has yielded conflicting results (156, 157). Some studies showed a significant decrease $(142,158)$, while others found no difference $(159,160)$. However, in accordance with two recent meta-analyses $(147,155)$, some blood studies have consistently found that increased levels of Hcy were found in the blood of ASD patients (Table 1) $(97,161)$.

Hcy is located at the intersection of the methionine cycle and trans-sulfuration pathway. The methionine cycle is responsible for the production of the universal methyl donor Sadenosylmethionine (SAM), which is used in a variety of methyl transfer reactions. The trans-sulfuration pathway is related to the synthesis of GSH (155). Changes in Hcy levels may have an impact on these two metabolic pathways. Impairment of methionine circulation, abnormal trans-sulfur metabolism (52, $142,158)$, and alterations in DNA methylation (162) have been shown to be associated with the development of ASD (155). The concentration of SAM in children with ASD was higher than that in the healthy controls, while SAM/S-adenosylhomocysteine (SAH) was significantly lower (147).

Various B vitamins such as B6 (pyridoxine), B9 (folic acid), and B12 (cobalamin) play important roles in the development, differentiation, and functioning of the central nervous system. They are involved in the methionine-homocysteine pathway (163). The levels of vitamin B9 and B12 in the blood of ASD children were significantly lower than those in the control group $(147,164,165)$. Their deficiency causes a decrease in homocysteine re-methylation, resulting in an increase in homocysteine levels (166). A lack of vitamin B12 may result in DNA hypomethylation, affecting the development of the central nervous system (167). Vitamin B deficiency can be caused by a lack of nutrients, poor absorption, or intestinal disorders. The gut microbiota is essential for digestion because it synthesizes essential dietary vitamins and cofactors such as vitamin B, riboflavin, thiamine, and folic acid (168). Folate deficiency and high Hcy levels are especially harmful to the neurological system $(169,170)$ because Hcy has neurotoxic characteristics (155).

Together, Hcy, vitamin B6, B9, and B12 may be associated with the pathophysiology of ASD. Figure 3 depicts the relationship between vitamins and the metabolism of Hcy. Children with ASD may have genetic and physiological disorders, poor lifestyle choices (including dietary habits), and a variety of pathological conditions, therefore monitoring their levels is important. Hcy studies are, however, heterogeneous, and more research is needed (155).

\section{MDA and 4-Hydroxynonenal}

Lipid peroxidation is an important part of oxidative stress and can be explained as a process in which ROS free radicals attack lipids containing carbon-carbon double bonds, especially polyunsaturated fatty acids (PUFAs) (171). Lipid peroxides are the main products in this process.

The phospholipid bilayer is primarily composed of PUFAs. When exposed to oxidative stress, ROS will constantly attack membrane lipids until they are depleted. Membrane lipid peroxidation results in a number of membrane changes, including increased membrane rigidity, decreased activity of membrane-bound enzymes, altered activity of membrane receptors, and altered permeability $(172,173)$. On the other hand, some PUFAs such as arachidonic acid (AA) can also be oxidized to various signaling molecules by specific enzymes like lipoxygenases (LO) and thus play a role in the regulation of many important physiological functions $(174,175)$. These signaling lipids include diacylglycerol (176-178), inositol phosphates (179-181), prostaglandins (182-184), and steroid hormones (185), etc. However, whether lipids are oxidized by enzyme action or by ROS attack, the process results in a variety of classic biomarkers of lipid peroxidation such as MDA, 4-HNE, and F2isoprostane, etc. A study reported that MDA and 4-HNE levels were higher in the frontal brain of ASD patients (186). This suggests that lipid peroxidation occurs in ASD patients' brains and may be related to the pathological process of ASD selfenhancement.

Despite the significant investigation, MDA has only been recognized as a signaling molecule in a few studies, such as regulation of islet glucose-stimulated insulin secretion (GSIS) (187) and gene expression of specificity protein-1 (Sp1) in hepatic stellate cells (188). MDA is known for its cytotoxicity, which occurs when it forms adducts with proteins, notably membrane proteins (189-192). MDA is also involved in DNA damage and mutation $(193,194)$, which leads to cell cycle cessation (195). In several studies of children with ASD, increased MDA content in the blood has been observed as a typical sign of lipid peroxidation $(23,119,128)$. In one study, however, MDA levels in the blood of ASD patients did not decrease 
TABLE 1 | The studies of potential oxidative stress biomarkers for ASD in the past 10 years.

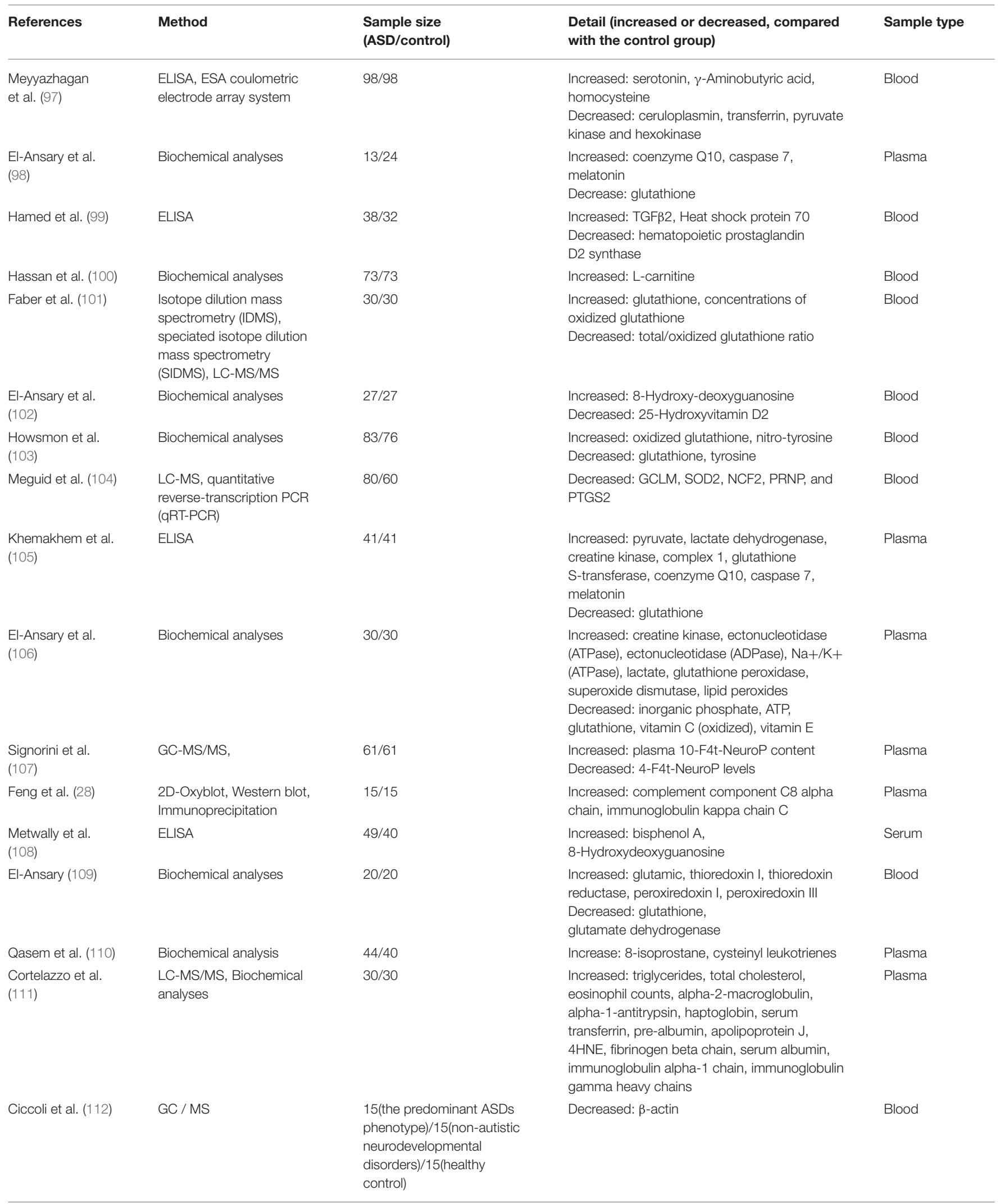


TABLE 1 | Continued

\begin{tabular}{|c|c|c|c|c|}
\hline References & Method & $\begin{array}{l}\text { Sample size } \\
\text { (ASD/control) }\end{array}$ & $\begin{array}{l}\text { Detail (increased or decreased, compared } \\
\text { with the control group) }\end{array}$ & Sample type \\
\hline Ghezzo et al. (29) & $\begin{array}{l}\text { Biochemical analyses, gas } \\
\text { chromatograph }\end{array}$ & $21 / 20$ & $\begin{array}{l}\text { Increased: thiobarbituric acid reactive } \\
\text { substances (TBARS), DHA- } \omega 6 / \omega 3 \text { ratio, } \\
\text { 1-6-phenyl-1,3,5-hexatriene (DPH), } \\
\text { 1-(4-trimethylammoniophenyl)-6-phenyl-1,3,5- } \\
\text { hexatriene (TMA-DPH) } \\
\text { Decreased: Na/K ATPase activity, erythrocyte } \\
\text { membrane fluidity, EPA, and DHA- } \omega 3 \text {, }\end{array}$ & Blood \\
\hline $\begin{array}{l}\text { Gorrindo et al. } \\
\text { (113) }\end{array}$ & $\mathrm{GC} / \mathrm{MS}$ & $\begin{array}{l}27(A S D \text { and GID)/29(ASD } \\
\text { without GID)/21(GID without } \\
\text { ASD)/10(control) }\end{array}$ & Increased: F2t-isoprostanes & Plasma \\
\hline Frye et al. (114) & $\begin{array}{l}\text { High-performance liquid } \\
\text { chromatography, } \\
\text { electrochemical detection }\end{array}$ & $\begin{array}{l}18(\mathrm{ASD} \text { with } \mathrm{MD}) / 18(\mathrm{ASD} \\
\text { without } \mathrm{MD}) / 18(\text { control) }\end{array}$ & $\begin{array}{l}\text { Increased: 3-chlorotyrosine } \\
\text { Decreased: free reduced glutathione, free } \\
\text { reduced glutathione/oxidized glutathione ratio }\end{array}$ & Plasma \\
\hline Essa et al. (117) & $\begin{array}{l}\text { Biochemical and data } \\
\text { analysis }\end{array}$ & $20 / 20$ & Decreased: ceruloplasmin, transferrin & Plasma \\
\hline $\begin{array}{l}\text { Lakshmi Priya and } \\
\text { Geetha (118) }\end{array}$ & SDS-PAGE, Western blot & $45 / 45$ & $\begin{array}{l}\text { Decreased: TBARS, glutathione, vitamin A, } \\
\text { vitamin C, superoxide dismutase }\end{array}$ & Blood \\
\hline Essa et al. (119) & Biochemical analyses & $19 / 19$ & $\begin{array}{l}\text { Increased: the levels of } \mathrm{NO} \text {, malondialdehyde, } \\
\text { protein carbonyl, and lactate to pyruvate ratio }\end{array}$ & Blood \\
\hline Rose et al. (120) & $\begin{array}{l}\text { PCR, Biochemical analyses, } \\
\text { Seahorse Extracellular Flux }\end{array}$ & $43 / 41$ & $\begin{array}{l}\text { Increased: glutathione } \\
\text { Decreased: oxidized glutathione disulfide }\end{array}$ & Blood \\
\hline $\begin{array}{l}\text { El-Ansary et al. } \\
\text { (124) }\end{array}$ & Biochemical analyses & $25 / 16$ & $\begin{array}{l}\text { Increased: acetic, valeric, hexanoic, stearidonic } \\
\text { Decreased: propionic, butyric, caprylic, } \\
\text { decanoic, lauric, palmitic, stearic, arachidic, } \\
\text { a-linolenic, eicosapentaenoic, } \\
\text { docosahexaenoic, linoleic, arachidonic, } \\
\text { oleic, elaidic }\end{array}$ & Plasma \\
\hline Ali et al. (125) & $\begin{array}{l}\text { Enzyme immunoassay, } \\
\text { automated random-access } \\
\text { immune-assay system }\end{array}$ & $40 / 40$ & $\begin{array}{l}\text { Increased: Hcy levels } \\
\text { Decreased: folate, vitamin B12 }\end{array}$ & Serum \\
\hline $\begin{array}{l}\text { AL-ayadhi and } \\
\text { Mostafa (126) }\end{array}$ & ELISA & $42 / 42$ & Increased: osteopontin & Serum \\
\hline
\end{tabular}


TABLE 1 | Continued

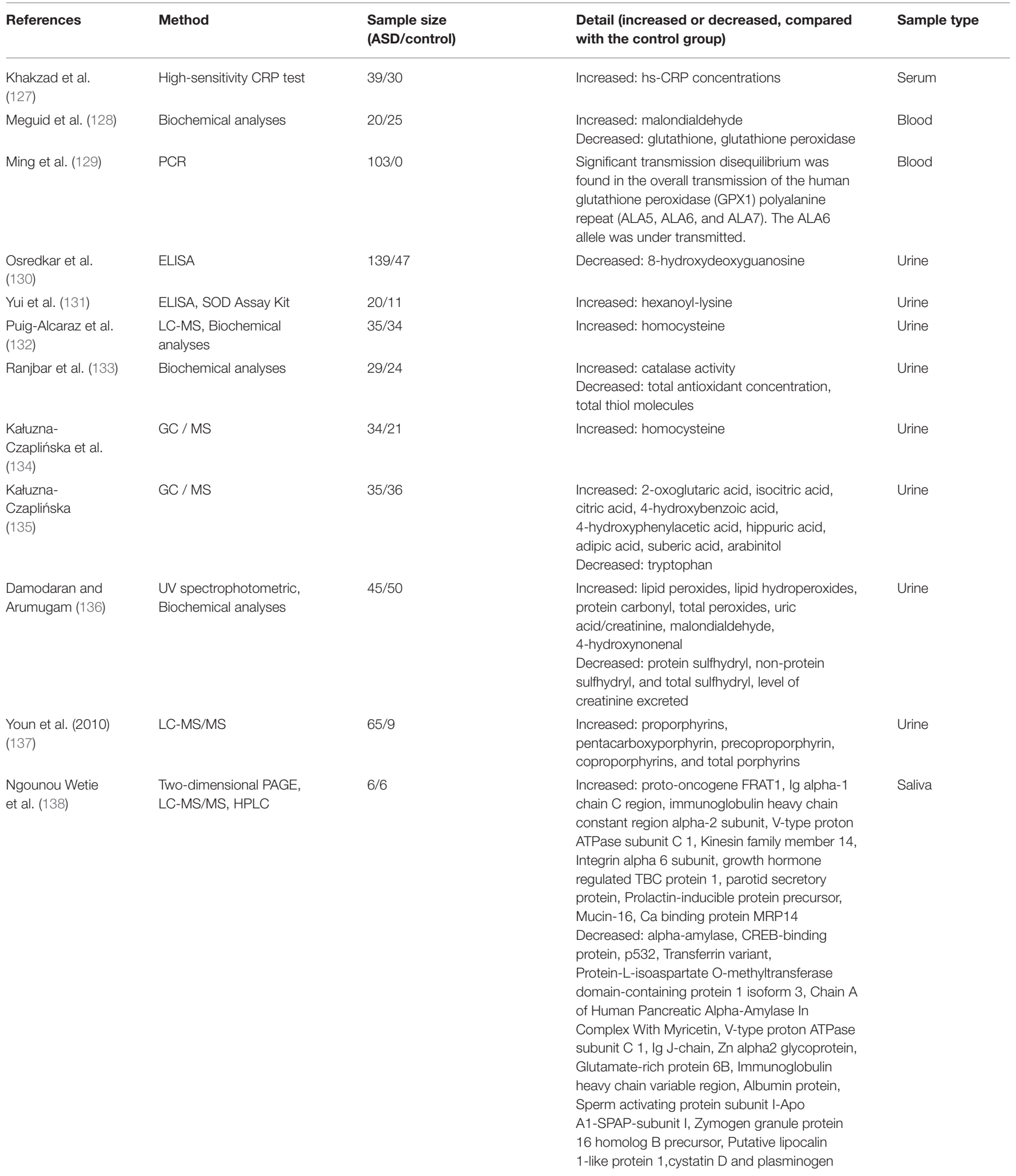


TABLE 1 | Continued

\begin{tabular}{|c|c|c|c|c|}
\hline References & Method & $\begin{array}{l}\text { Sample size } \\
\text { (ASD/control) }\end{array}$ & $\begin{array}{l}\text { Detail (increased or decreased, compared } \\
\text { with the control group) }\end{array}$ & Sample type \\
\hline Anwar et al. (139) & LC-MS/MS & $38 / 31$ & $\begin{array}{l}\text { Increased in plasma: } \mathrm{N} \varepsilon \text {-carboxymethyl-lysine, } \\
\mathrm{N} \omega \text {-carboxymethylarginine, dityrosine } \\
\text { Increased in urine: alpha-aminoadipic } \\
\text { semialdehyde, glutamic semialdehyde, asn, } \\
\text { pro, ser, and val } \\
\text { Renal clearance of carboxymethylarginine, } \\
\text { glucosepane, dityrosine, arg, glu, leu, phe, and } \\
\text { thr were decreased and renal clearance of } \\
\mathrm{N} \text {-formylkynurenine and trp were increased in } \\
\text { children with ASD, with respect to } \\
\text { healthy controls. }\end{array}$ & Plasma and urine \\
\hline $\begin{array}{l}\text { Yenkoyan et al. } \\
(140)\end{array}$ & $\begin{array}{l}\text { LC-MS/MS, ICP-MS, flow } \\
\text { cytometry }\end{array}$ & $10 / 10$ & $\begin{array}{l}\text { Increased: 8-hydroxy-2'-deoxyguanosine } \\
\text { Decreased: superoxide dismutase }\end{array}$ & Blood and urine \\
\hline
\end{tabular}

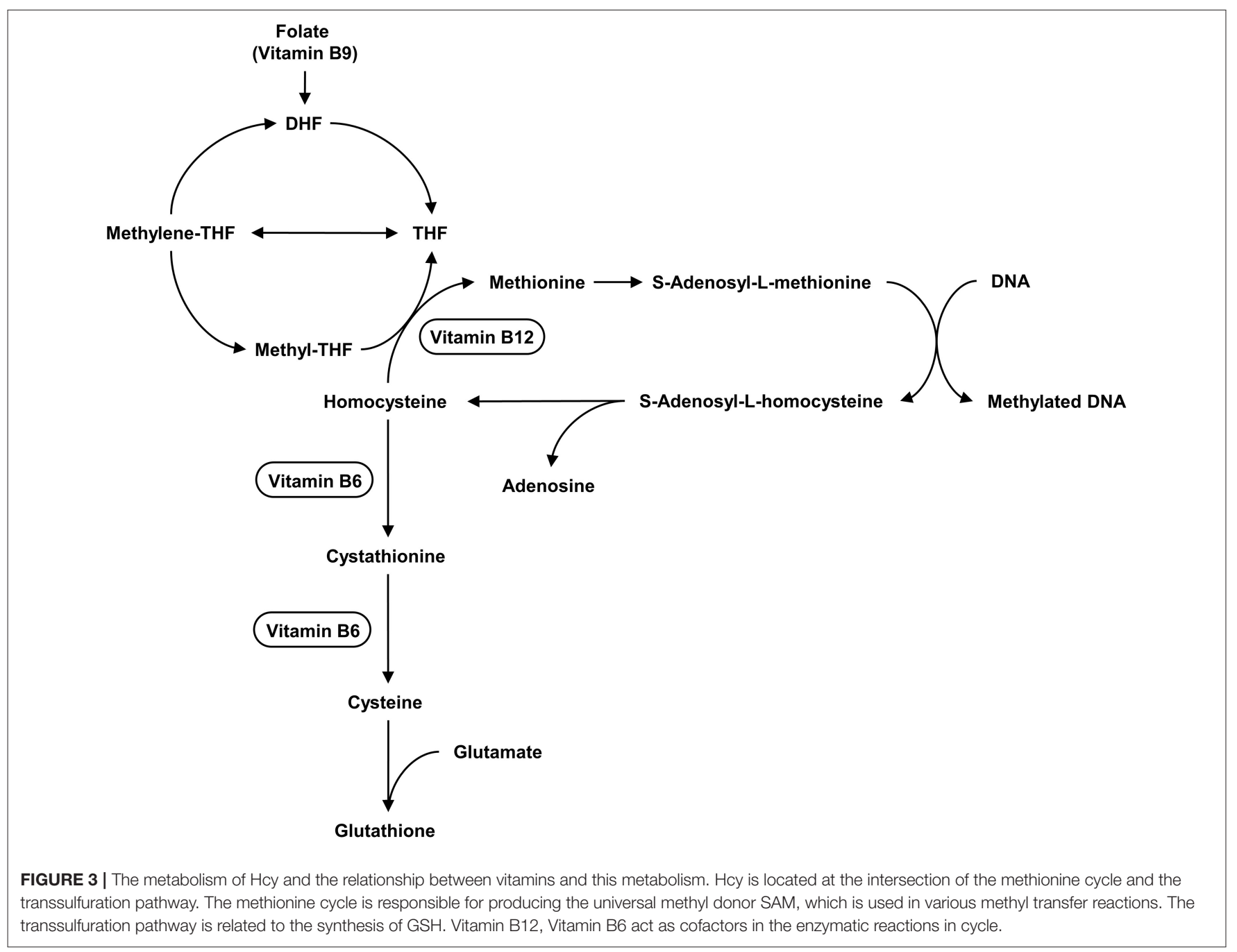

significantly (196). In fact, this discrepancy could be due to the measurement method. Thiobarbituric acid reactive substances (TBARS) is a well-known MDA measurement method based on MDA and thiobarbituric acid reaction (TBA) (197). However, this method is non-specific because many carbonyl compounds such as some oxidized unsaturated fatty acids have been shown to react with TBA and interfere with MDA measurement (198). In addition, according to the biochemical properties of MDA, 
biological MDA will exist in two forms: free MDA and adducted MDA with proteins, nucleic acids, lipoproteins, and amino acids (199). Some researchers attempted to detect MDA using liquid chromatography-mass spectrometry (LC-MS) and gas chromatography-mass spectrometry (GC-MS), which showed to be more specific and sensitive than TBARS analysis, as well as effective for both free and adducted MDA $(200,201)$. Except in blood investigations, amino acid adducts of MDA, such as Nepsilon-(2-propenal) lysine, $\mathrm{N}$ - $\alpha$-acetyl-(epsilon)-(2-propenal) lysine, $\mathrm{N}$-(2-propenal) serine, and N-(2-propenal) ethanolamine (202-205) have been found in urine by mass spectrometry.

4-HNE is also a lipid peroxidation end product and one of the most cytotoxic products. Once produced in cells, its elimination depends mainly on the action of antioxidants like GSH. It is intriguing that 4 -HNE, as a signaling molecule, can regulate the expression of many transcription factors while enhancing the antioxidant mechanism of cells. These transcription factors include nuclear factor erythroid 2-related factor 2 (Nrf2) (206, 207), activating protein-1 (AP-1) (208), and peroxisome proliferator-activated receptors (PPAR) $(209,210)$, etc. At the same time, 4-HNE is highly cytotoxic causing protein and DNA damage (199, 211-213), affecting autophagy $(214,215)$, and inducing cell apoptosis (216). Furthermore, high concentrations of 4-HNE can cause cell necrosis (217). Similar to the biochemical properties of MDA, biological 4-HNE also exists in two forms, including free 4-HNE or adducted 4-HNE with proteins, nucleic acids, lipoproteins, and amino acids (152). Based on the HPLCbased free 4-HNE measurement method, 4-HNE absorbs (197) in the UV range (220-223 nm). Other more specific and sensitive probes that are widely used are aldehyde reaction probes such as 2,4-dinitrophenylhydrazine (DNPH) and 1,3-cyclohexanedione (CHD) (218). UV spectrophotometry was used in a study to detect significant increases of 4-HNE in the urine of children with ASD (136). These methods, like MDA, are non-specific because they cannot distinguish 4-HNE from other aldehydes. The early measuring method of adducted 4-HNE, on the other hand, is an immunoassay, which relies on antibodies specific for 4-HNE bound to proteins or other biomolecules $(219,220)$. Using a Western blot assay, a study found a significantly higher level of 4-HNE protein adducts (4-HNE PAs) in the plasma of children with ASD (221). Many specific detection methods for 4-HNE, including adducted 4-HNE based on LC-MS or GC-MS, have been developed as a result of the advancement of mass spectrometry technology, and are now widely used in the detection of biomarkers of various oxidative stress diseases (222). Unfortunately, few studies have focused on 4-HNE as a biomarker in ASD. A study on the brain tissue from ASD patients showed that cellular stress and apoptosis caused by 4-HNE in the brain may contribute to the pathogenesis of ASD (223), implying that 4-HNE is a worthy research direction.

In addition to MDA and 4-HNE, the most prominent markers of lipid peroxidation, such as isoprostanes, have been established as biomarkers and have received extensive attention. Multiple studies have discovered elevated levels of isoprostane in blood samples from children with ASD, as indicated in Table 1 (65, 68, 70). More study is needed at this time on the types of biomarkers and application methods that can more correctly identify the extent of lipid peroxidation in patients.

\section{Urine Based Biomarker}

As shown in Table 1, there have been few biomarker studies of oxidative stress in ASD utilizing urine samples. Despite the fact that blood has a more complicated composition, urine biomarker studies have lagged behind those in the blood (224). This could be related to the fact that urine biomarkers are limited. Gender, age, collection time, dietary choices, and kidney injury are only a few of the factors that produce changes in urine components. Because urine is more unstable than blood, reliable biomarkers must be revealed before it can be discovered. Furthermore, several high-abundance proteins in urine, such as uromodulin, albumin, and immunoglobulin, might obstruct the detection of low-abundance proteins. As a result, enlarging low abundance urine proteins or eliminating high abundance urinary proteins should be considered (225).

Although there are certain limitations to detecting biomarkers in urine, urinary biomarkers still offer great potential and advantages. Urine is one of the body's principal excretory systems, containing a variety of proteins and metabolites, many of which are well-described in both normal and pathological conditions (226). Urine collection is safer, more convenient, and yields a bigger sample volume when compared to other peripheral bodily fluids. Because urine generation is linked to plasma filtration and selective reabsorption, changes in urine components can signal not only the presence of disorders like diabetes and kidney disease but also the presence of changes in blood components.

Interestingly, as indicated in Table 1, oxidative stress biomarkers have been found in the blood and urine of ASD patients in several studies $(139,140)$. These investigations focus on the antioxidant capacity of blood and urine, as well as enzyme antioxidant activity and redox reaction intermediates. Hcy levels in blood and urine have been observed to be higher in children with ASDs in prior research $(125,134,227)$. Hcy levels in urine and blood of autistic people appear to be the same, implying that changes in Hcy levels in the urine may reflect changes in the blood while collecting urine samples is non-invasive, safe, and easy.

\section{ASD TREATMENT AND OXIDATIVE STRESS}

To learn more about the pathophysiology and diagnostic biomarkers of ASD, researchers are currently studying effective drugs and treatments (228). Increased oxidative stress is a common feature in ASD individuals, despite the fact that ASD is heterogeneous. Intervening and treating oxidative stress is one of the most effective techniques for improving the pathogenetic status of ASD patients. Therefore, various antioxidants, including sulforaphane (229), resveratrol (230-233), N-acetylcysteine (NAC) $(234,235)$, hesperidin (236), flavonoid $(237,238)$, leptin (239), minocycline, and doxycycline (240), selenium supplements (241), docosahexaenoic acid (DHA) (242), curcumin (243), agmatine (244), and sulindac (245), etc., have been reported to be employed in ASD treatment animal model experiments. In these studies, all of these antioxidants 
have shown positive therapeutic effects, indicating that they could be useful in the treatment of ASD.

Antioxidant therapy for ASD has only a few clinical investigations. Sulforaphane (246), resveratrol (247), coenzyme Q10 (248), NAC (249), omega-3 fatty acids (250), arachidonic acid, and DHA (251) are some of the antioxidant supplements used in these studies to treat ASD. All of these antioxidants, with the exception of resveratrol, are beneficial. Although resveratrol plays a beneficial role in the treatment of ASD animal model, its clinical study was still in its infancy. Currently, it has only one clinical study and the result is negative (252). Interestingly, a systematic review of treatments based on antioxidants reported that NAC appears to be the most effective antioxidant therapy of ASD currently (253). Furthermore, supplementing micronutrients for redox metabolism has been demonstrated to be helpful in certain children with autism (254). Treatment of ASD patients with antioxidant-rich food, on the other hand, is also a viable option. Several studies have evaluated the effectiveness of antioxidant-rich foods including broccoli (255), camel milk (256), and dark chocolate for ASD (257).

Overall, the results of these studies are positive. But as expected, some of the treatment groups in these clinical studies showed strong individual differences, reflecting the heterogeneity of ASD. It is important to note that ROS is a general term, not a specific molecule. As mentioned above, it contains a set of molecules derived from molecular oxygen, and the chemical reactivity of various ROS molecules varies widely as far as antioxidants are concerned, there are many types of antioxidants, and their specific antioxidant functions are also different. Antioxidants always have a goal that can only handle one type of ROS and not another $(46,47,49)$. The causes of oxidative stress in ASD patients may differ due to genetic differences and the diversity of antioxidant defenses against oxidative stress. Using biomarkers to determine the types of antioxidants taken by each ASD patient and then supplementing them might be more successful. Antioxidants have been demonstrated to enhance behavior in persons with ASD in numerous research, however, these effects are generally transient, and only a few studies have shown a long-term behavioral reversal in people with ASD (228). Therefore, effective biomarkers for monitoring the efficacy of antioxidative therapy in ASD patients should be considered.

Some of the antioxidants mentioned above, such as sulforaphane, resveratrol, naringenin, curcumin, and agmatine, work as both antioxidants and Nrf2 activators (252). Nrf2 is a transcription factor implicated in immunological dysregulation/inflammation, oxidative stress, and mitochondrial dysfunction. Nrf2 is generally coupled to Kelch-like ECHassociated protein 1 (Keap1) in an inactive form, and the ubiquitin-proteasome system destroys the complex, allowing cells to maintain a steady low level of Nrf2 (258). The complex dissociates when subjected to oxidative stress, and Nrf2 translocates to the nucleus. Before binding to specific DNA locus antioxidant response elements (AREs), Nrf2 will heterodimerize with Maf or Jun proteins in the nucleus $(259,260)$. NRF2-ARE binding can regulate the expression of hundreds of cytoprotective genes including antioxidant proteins and phase II enzymes (261). Furthermore, the Nrf2/ARE pathway interacts with the NF- $\kappa$ B (nuclear factor kappa-light-chain-enhancer of activated B cells) pathway. The p65 subunit of NF- $\mathrm{B}$ inhibits the Nrf2/ARE pathway by depriving CREB binding protein (CBP), allowing HDAC3 to recruit to MafK and interact with Keap1 $(262,263)$. Alternatively, free Keap1 can inhibit the NF- $\kappa$ B pathway by regulating the activity of the inhibitor of nuclear factor- $\kappa \mathrm{B}$ kinase subunit beta (IKK- $\beta$ ) (264). NF- $\mathrm{kB}$ is a key player in the regulation of inflammation (265), as is involved in the release of pro-inflammatory cytokines such as IL-1, IL-6, IL-12, and TNF- $\alpha$ (266). Several studies have also shown that Nrf2 can directly regulate the availability of mitochondrial respiratory substrates, resulting in mitochondrial depolarization, reduced ATP levels, and impaired respiratory function. Furthermore, the aforementioned negative phenomena can be reversed by activating the Nrf2 pathway $(267,268)$.

Moreover, when induced with lipopolysaccharide (LPS), Nrf2-deficient mice have a more pronounced release of ROS, microglial activation, and neuro-inflammatory response than normal mice (269). Some studies of BTBR mice (a model of ASD) indicated that the Nrf2 system plays an important role in the regulation of neuroinflammation and oxidative stress in the brain $(229,270)$. A study in monocytes from people with ASD found a positive result by regulating the Nrf2 system in an in vitro LPSinduced inflammatory model (271) and many other studies have reported the abnormalities of the Nrf2 system in ASD individuals (272, 273). Therefore, the Nrf2 system is one of the important ways of antioxidant therapy. A systematic review of treatments based on the Nrf2 system shows a potentially beneficial result, but also explains that these treatments still lack sufficient evidence for their efficacy and safety (252). Better design and more rigorous research are needed before the treatments can be used.

\section{LIMITATIONS OF CURRENT STUDIES AND PROSPECTS}

Disease progression, including ASD, is often accompanied by dramatic changes in the levels of various proteins and metabolites. Biomarkers can be used to comprehensively monitor the physiological status of ASD patients during diagnosis, intervention, and treatment, which can aid in understanding the condition, judging the treatment strategy, and monitoring efficacy and prognosis (3, 10). To this purpose, the efficacy of biomarkers and biological detection systems must meet stringent requirements. Traditional detection methods, such as Western blot analysis and enzyme-linked immunosorbent assay (ELISA), can not detect many markers at once, making comprehensive control difficult. The sensitivity of biological detection technology has improved, and more detection scenarios have been implemented, allowing for more comprehensive monitoring. Mass spectrometry has seen tremendous advancements in recent years, particularly in terms of reproducibility, performance, resolution, precision, and analytical quality.

Currently, mass spectrometry-based targeted proteomic or metabolomic approaches can effectively monitor multiple disease 
markers simultaneously $(3,10)$. Several targeted metabolomic techniques to oxidative stress markers have been developed (274) and utilized (275). Methionine, homocysteine, vitamins B6, B12, B9, and their metabolites have been accurately measured in several matrices, including breast milk, plasma, and neonatal mouse brain, using a novel approach (274). Concomitant vitamin B6, B9, and B12 deficits, as well as lower levels of methionine, GSH, SAM, and a lower SAM/SAH ratio, as well as Hcy, SAH, and 5-methyltetrahydrofolate (5methyltetrahydrofuran) in children's urine samples, have all been linked to autism (275).

At the same time, because the brain is a part of the central nervous system and is susceptible to oxidative stress, numerous physiological abnormalities generated by oxidative stress in the brain would play a role in the development of autism. For the diagnosis and treatment of ASD, identifying the oxidative stress that occurs in the peripheral or brain is beneficial. Brain-derived neurotrophic factor (BDNF) (276), brain-derived exosomes (277), and other plasma brain-derived ASD biomarkers, have been discovered in numerous research. However, though some studies also reported some plasma biomarkers for brain oxidative damage by analyzing different kinds of samples including F4-Neuroprostanes and F2-DihomoIsoprostanes (278), biomarkers in peripheral body fluid samples are still insufficient to identify brain or peripheral oxidative stress at the moment. Although cerebrospinal fluid (CSF) samples can detect oxidative stress in the brain, they are not appropriate for patients with ASD due to the risk of injury during the sampling process. Because of their ease of collection, peripheral bodily fluid samples are always the best option.

Furthermore, little research has been done on peripheral blood cells, which play an important role in the immune system. Since a relationship has been demonstrated between oxidative stress and systemic inflammation $(82,83)$, peripheral oxidative stress and inflammation in ASD patients cannot be ignored. There is a lot of evidence that peripheral immune cells like $\mathrm{T}$ cells and $\mathrm{B}$ cells can affect brain neurons and can contribute to brain inflammation in some neural diseases (279).

With significant advances in biomedical detection technology, the limitations and defects of previous studies will be improved. Otherwise, some significant topics closely related to oxidative stress of ASD such as brainderived factors and peripheral blood cells are worthy and promising.

\section{REFERENCES}

1. American Psychiatric Association. Diagnostic and Statistical Manual of Mental Disorders: DSM-5. 5th edn. Washington, DC: American Psychiatric Association (2013). 947p. doi: 10.1176/appi.books.9780890425596

2. Barnard-Brak L, Richman DM, Chesnut SR, Little TD. Social communication questionnaire scoring procedures for autism spectrum disorder and the prevalence of potential social communication disorder in ASD. Sch Psychol Q. (2016) 31:522-33. doi: 10.1037/spq0000144

\section{CONCLUSION}

Many studies have demonstrated that oxidative stress plays a crucial part in the disease process of ASD because ASD cases have greater levels of oxidative stress and decreased antioxidant capability. The active use of biomarkers to monitor ASD patients' physiological status is helpful for disease diagnosis, intervention, and treatment. We mainly summarize the most recent research progress in the field of ASD oxidative stress biomarkers in this review. Many possible oxidative stress markers have been discovered in ASD, however, attempts to monitor the oxidative stress status of children with ASD are still difficult to meet clinical application standards, and additional study is needed. At the same time, we present a review of recent studies on antioxidant interventions. Several clinical investigations have found significant individual differences in some therapy groups, indicating that ASD is heterogeneous. With the development of mass spectrometry technology, mass spectrometry-based proteomics, and metabolomic methods have gradually become powerful tools for exploring biomarkers. These methods make ASD biomarker research easier and help to expand the depth and breadth of biomarker research.

\section{AUTHOR CONTRIBUTIONS}

$\mathrm{XL}$ and LS contributed to conception and design of the study. JL, HZ, JZ and XT collected related literature and tabulated it. XL wrote the first draft of the manuscript. XL, $\mathrm{NK}, \mathrm{XC}$ and LS wrote sections of the manuscript. All authors contributed to manuscript revision, read, and approved the submitted version.

\section{FUNDING}

This article was supported by the National Natural Science Foundation of China (Grant No. 31870825), the Shenzhen Bureau of Science, Technology, and Information (Grant Nos. JCYJ20170412110026229 and JCYJ20200812122708001), and the Shenzhen-Hong Kong Institute of Brain Science-Shenzhen Fundamental Research Institutions (Grant Nos. 2019 SHIBS0003 and 2021SHIBS0003).

\section{ACKNOWLEDGMENTS}

We thank the Instrument Analysis Center of Shenzhen University.
3. Shen L, Liu X, Zhang H, Lin J, Feng C, Iqbal J. Biomarkers in autism spectrum disorders: current progress. Clin Chim Acta. (2020) 502:4154. doi: 10.1016/j.cca.2019.12.009

4. Zhang J, Li X, Shen L, Khan NU, Zhang X, Chen L, et al. Trace elements in children with autism spectrum disorder: a metaanalysis based on case-control studies. J Trace Elem Med Biol. (2021) 67:126782. doi: $10.1016 /$ j.jtemb.2021.126782

5. Wiśniowiecka-Kowalnik B, Nowakowska BA. Genetics and epigenetics of autism spectrum disorder-current evidence in the 
field. J Appl Genet. (2019) 60:37-47. doi: 10.1007/s13353-018-00 480-W

6. Yoo H. Genetics of autism spectrum disorder: current status and possible clinical applications. Exp Neurobiol. (2015) 24:257-72. doi: 10.5607/en.2015.24.4.257

7. Emberti Gialloreti L, Mazzone L, Benvenuto A, Fasano A, Alcon AG, Kraneveld A, et al. Risk and protective environmental factors associated with autism spectrum disorder: evidence-based principles and recommendations. J Clin Med. (2019) 8:E217. doi: 10.3390/jcm8020217

8. Madore C, Leyrolle Q, Lacabanne C, Benmamar-Badel A, Joffre C, Nadjar A, et al. Neuroinflammation in autism: plausible role of maternal inflammation, dietary omega 3, and microbiota. Neural Plast. (2016) 2016:3597209. doi: 10.1155/2016/3597209

9. Bölte S, Girdler S, Marschik PB. The contribution of environmental exposure to the etiology of autism spectrum disorder. Cell Mol Life Sci. (2019) 76:127597. doi: $10.1007 /$ s00018-018-2988-4

10. Shen L, Zhao Y, Zhang H, Feng C, Gao Y, Zhao D, et al. Advances in biomarker studies in autism spectrum disorders. Adv Exp Med Biol. (2019) 1118:207-33. doi: 10.1007/978-3-030-05542-4_11

11. Faras H, Al Ateeqi N, Tidmarsh L. Autism spectrum disorders. Ann Saudi Med. (2010) 30:295-300. doi: 10.4103/0256-4947.65261

12. Farmer C, Thurm A, Grant P. Pharmacotherapy for the core symptoms in autistic disorder: current status of the research. Drugs. (2013) 73:30314. doi: $10.1007 /$ s40265-013-0021-7

13. Landa RJ. Efficacy of early interventions for infants and young children with, and at risk for, autism spectrum disorders. Int Rev Psychiatry. (2018) 30:25-39. doi: 10.1080/09540261.2018.1432574

14. Zwaigenbaum L, Bauman ML, Choueiri R, Kasari C, Carter A, Granpeesheh $\mathrm{D}$, et al. Early intervention for children with autism spectrum disorder under 3 years of age: recommendations for practice and research. Pediatrics. (2015) 136 (Suppl. 1):S60-81. doi: 10.1542/peds.2014-3667E

15. Zwaigenbaum L, Bauman ML, Fein D, Pierce K, Buie T, Davis PA, et al. Early screening of autism spectrum disorder: recommendations for practice and research. Pediatrics. (2015) 136 (Suppl. 1):S41-59. doi: 10.1542/peds.2014-3667D

16. Masi A, DeMayo MM, Glozier N, Guastella AJ. An overview of autism spectrum disorder, heterogeneity and treatment options. Neurosci Bull. (2017) 33:183-93. doi: 10.1007/s12264-017-0100-y

17. Ruggeri B, Sarkans U, Schumann G, Persico AM. Biomarkers in autism spectrum disorder: the old and the new. Psychopharmacology. (2014) 231:1201-16. doi: 10.1007/s00213-013-3290-7

18. Yao F, Zhang K, Feng C, Gao Y, Shen L, Liu X, et al. Protein biomarkers of autism spectrum disorder identified by computational and experimental methods. Front Psychiatry. (2021) 12:554621. doi: 10.3389/fpsyt.2021.554621

19. Baxter AJ, Brugha TS, Erskine HE, Scheurer RW, Vos T, Scott JG. The epidemiology and global burden of autism spectrum disorders. Psychol Med. (2015) 45:601-13. doi: 10.1017/S003329171400172X

20. Shen L, Feng C, Zhang K, Chen Y, Gao Y, Ke J, et al. Proteomics study of peripheral blood mononuclear cells (PBMCs) in autistic children. Front Cell Neurosci. (2019) 13:105. doi: 10.3389/fncel.2019.00105

21. Shen L, Zhang K, Feng C, Chen Y, Li S, Iqbal J, et al. iTRAQ-Based proteomic analysis reveals protein profile in plasma from children with autism. Proteomics. (2018) 12:1700085. doi: 10.1002/prca.201700085

22. Depino AM. Peripheral and central inflammation in autism spectrum disorders. Mol Cell Neurosci. (2013) 53:6976. doi: 10.1016/j.mcn.2012.10.003

23. Al-Gadani Y, El-Ansary A, Attas O, Al-Ayadhi L. Metabolic biomarkers related to oxidative stress and antioxidant status in Saudi autistic children. Clin Biochem. (2009) 42:1032-40. doi: 10.1016/j.clinbiochem.2009.03.011

24. Rose S, Melnyk S, Pavliv O, Bai S, Nick TG, Frye RE, et al. Evidence of oxidative damage and inflammation associated with low glutathione redox status in the autism brain. Transl Psychiatry. (2012) 2:e134. doi: 10.1038/tp.2012.61

25. Sweeten TL, Posey DJ, Shankar S, McDougle CJ. High nitric oxide production in autistic disorder: a possible role for interferongamma. Biol Psychiatry. (2004) 55:434-7. doi: 10.1016/j.biopsych.2003. 09.001
26. Rossignol DA, Frye RE. Mitochondrial dysfunction in autism spectrum disorders: a systematic review and meta-analysis. Mol Psychiatry. (2012) 17:290-314. doi: 10.1038/mp.2010.136

27. Sajdel-Sul EM, Lipinski B, Windom H, Audhya T, McGinnis W. Oxidative stress in autism: elevated cerebellar 3-nitrotyrosine levels. Am J Biochem Biotechnol. (2008) 4:73-84. doi: 10.3844/ajbbsp.2008.73.84

28. Feng C, Chen Y, Pan J, Yang A, Niu L, Min J, et al. Redox proteomic identification of carbonylated proteins in autism plasma: insight into oxidative stress and its related biomarkers in autism. Clin Proteomics. (2017) 14:1-8. doi: 10.1186/s12014-017-9138-0

29. Ghezzo A, Visconti P, Abruzzo PM, Bolotta A, Ferreri C, Gobbi $\mathrm{G}$, et al. Oxidative stress and erythrocyte membrane alterations in children with autism: correlation with clinical features. PLOS ONE. (2013) 8:e66418. doi: 10.1371/journal.pone.0066418

30. Sies $\mathrm{H}$, editor. Oxidative Stress. In: International Journal of Biochemistry. London: Academic Press (1986). p. 493. doi: 10.1016/0020-711X(86)90197-7

31. Aviello G, Knaus UG. NADPH oxidases and ROS signaling in the gastrointestinal tract. Mucosal Immunol. (2018) 11:101123. doi: $10.1038 / \mathrm{s} 41385-018-0021-8$

32. Bedard K, Krause K-H. The NOX family of ROS-generating NADPH oxidases: physiology and pathophysiology. Physiol Rev. (2007) 87:245313. doi: 10.1152 /physrev.00044.2005

33. Davies MJ, Hawkins CL. The role of myeloperoxidase in biomolecule modification, chronic inflammation, and disease. Antioxid Redox Signal. (2020) 32:957-81. doi: 10.1089/ars.2020.8030

34. Aktan F. iNOS-mediated nitric oxide production and its regulation. Life Sci. (2004) 75:639-53. doi: 10.1016/j.lfs.2003.10.042

35. Steinert JR, Chernova T, Forsythe ID. Nitric oxide signaling in brain function, dysfunction, and dementia. Neuroscientist. (2010) 16:43552. doi: $10.1177 / 1073858410366481$

36. Tse JKY. Gut microbiota, nitric oxide, and microglia as prerequisites for neurodegenerative disorders. ACS Chem Neurosci. (2017) 8:143847. doi: 10.1021/acschemneuro.7b00176

37. Jodeiri Farshbaf M, Kiani-Esfahani A. Succinate dehydrogenase: prospect for neurodegenerative diseases. Mitochondrion. (2018) 42:77-83. doi: 10.1016/j.mito.2017.12.002

38. Lenaz G. The mitochondrial production of reactive oxygen species: mechanisms and implications in human pathology. IUBMB Life. (2001) 52:159-64. doi: 10.1080/15216540152845957

39. Mrácek T, Pecinová A, Vrbacký M, Drahota Z, Houstek J. High efficiency of ROS production by glycerophosphate dehydrogenase in mammalian mitochondria. Arch Biochem Biophys. (2009) 481:30-6. doi: 10.1016/j.abb.2008.10.011

40. Whatley SA, Curti D, Das Gupta F, Ferrier IN, Jones S, Taylor C, et al. Superoxide, neuroleptics and the ubiquinone and cytochrome b5 reductases in brain and lymphocytes from normals and schizophrenic patients. Mol Psychiatry. (1998) 3:227-37. doi: 10.1038/sj.mp.4000375

41. Hauptmann N, Grimsby J, Shih JC, Cadenas E. The metabolism of tyramine by monoamine oxidase $\mathrm{A} / \mathrm{B}$ causes oxidative damage to mitochondrial DNA. Arch Biochem Biophys. (1996) 335:295-304. doi: 10.1006/abbi.1996.0510

42. Vasquez-Vivar J, Kalyanaraman B, Kennedy MC. Mitochondrial aconitase is a source of hydroxyl radical. An electron spin resonance investigation. J Biol Chem. (2000) 275:14064-9. doi: 10.1074/jbc.275.19.14064

43. Vorbach C, Harrison R, Capecchi MR. Xanthine oxidoreductase is central to the evolution and function of the innate immune system. Trends Immunol. (2003) 24:512-7. doi: 10.1016/S1471-4906(03)00237-0

44. Starkov AA, Fiskum G, Chinopoulos C, Lorenzo BJ, Browne SE, Patel MS, et al. Mitochondrial alpha-ketoglutarate dehydrogenase complex generates reactive oxygen species. J Neurosci. (2004) 24:7779-88. doi: 10.1523/JNEUROSCI.1899-04.2004

45. Andreyev AY, Kushnareva YE, Starkov AA. Mitochondrial metabolism of reactive oxygen species. Biochemistry. (2005) 70:200-14. doi: 10.1007/s10541-005-0102-7

46. Halliwell B, Gutteridge JMC. Free radicals in biology and medicine. J Free Radic Biol Med. (1985) 1:331-2. doi: 10.1016/0748-5514(85)90140-0

47. Sies H, Berndt C, Jones DP. Oxidative stress. Annu Rev Biochem. (2017) 86:715-48. doi: 10.1146/annurev-biochem-061516-045037 
48. Niki E. Oxidative stress and antioxidants: distress or eustress? Arch Biochem Biophys. (2016) 595:19-24. doi: 10.1016/j.abb.2015.11.017

49. Murphy MP, Holmgren A, Larsson N-G, Halliwell B, Chang CJ, Kalyanaraman B, et al. Unraveling the biological roles of reactive oxygen species. Cell Metab. (2011) 13:361-6. doi: 10.1016/j.cmet.2011.03.010

50. Costanzo M, Boschi F, Carton F, Conti G, Covi V, Tabaracci G, et al. Low ozone concentrations promote adipogenesis in human adipose-derived adult stem cells. Eur J Histochem. (2018) 62:2969. doi: 10.4081/ejh.2018.2969

51. Galiè M, Costanzo M, Nodari A, Boschi F, Calderan L, Mannucci $\mathrm{S}$, et al. Mild ozonisation activates antioxidant cell response by the Keap1/Nrf2 dependent pathway. Free Radic Biol Med. (2018) 124:11421. doi: 10.1016/j.freeradbiomed.2018.05.093

52. James SJ, Rose S, Melnyk S, Jernigan S, Blossom S, Pavliv O, et al. Cellular and mitochondrial glutathione redox imbalance in lymphoblastoid cells derived from children with autism. FASEB J. (2009) 23:237483. doi: 10.1096/fi. $08-128926$

53. Fernández-Checa JC, Kaplowitz N, García-Ruiz C, Colell A, Miranda M, Marí M, et al. GSH transport in mitochondria: defense against TNF-induced oxidative stress and alcohol-induced defect. Am J Physiol. (1997) 273:G717. doi: 10.1152/ajpgi.1997.273.1.G7

54. Miyazawa T, Burdeos GC, Itaya M, Nakagawa K, Miyazawa T. Vitamin E: regulatory redox interactions: vitamin $\mathrm{E}$ : regulatory redox interactions. IUBMB Life. (2019) 71:430-41. doi: 10.1002/iub.2008

55. Manivasagam T, Arunadevi S, Essa MM, SaravanaBabu C, Borah A, Thenmozhi AJ, et al. Role of oxidative stress and antioxidants in autism. Adv Neurobiol. (2020) 24:193-206. doi: 10.1007/978-3-030-30402-7_7

56. Cuce G, Canbaz H, Sozen M, Yerlikaya F, Kalkan S. Vitamin E and selenium treatment of monocrotaline induced hepatotoxicity in rats. Biotech Histochem. (2017) 92:59-67. doi: 10.1080/10520295.2016.1267798

57. Hedayati M, Niazmand S, Hosseini M, Baghcheghi Y, Beheshti F, Niazmand S. Vitamin E improved redox homeostasis in heart and aorta of hypothyroid rats. Endocrine Regul. (2017) 51:205-12. doi: 10.1515/enr-2017-0021

58. Beheshti F, Karimi S, Vafaee F, Shafei MN, Sadeghnia HR, Hadjzadeh MAR, et al. The effects of vitamin $\mathrm{C}$ on hypothyroidism-associated learning and memory impairment in juvenile rats. Metab Brain Dis. (2017) 32:70315. doi: 10.1007/s11011-017-9954-y

59. Venkataraman P, Muthuvel R, Krishnamoorthy G, Arunkumar A, Sridhar M, Srinivasan N, et al. PCB (Aroclor 1254) enhances oxidative damage in rat brain regions: protective role of ascorbic acid. NeuroToxicology. (2007) 28:490-8. doi: 10.1016/j.neuro.2006.11.002

60. Diniz TC, Silva JC, Lima-Saraiva SRG de, Ribeiro FPR de A, Pacheco AGM, de Freitas RM, et al. The role of flavonoids on oxidative stress in epilepsy. Oxid Med Cell Longev. (2015) 2015:1-9. doi: 10.1155/2015/171756

61. Mehrabadi S, Sadr SS. Administration of vitamin D3 and E supplements reduces neuronal loss? and oxidative stress in a model of rats with Alzheimer's disease. Neurol Res. (2020) 42:862-8. doi: 10.1080/01616412.2020.1787624

62. Ribeiro D, Freitas M, Silva AMS, Carvalho F, Fernandes E. Antioxidant and pro-oxidant activities of carotenoids and their oxidation products. Food Chem Toxicol. (2018) 120:681-99. doi: 10.1016/j.fct.2018.07.060

63. Higgins MR, Izadi A, Kaviani M. Antioxidants and exercise performance: with a focus on vitamin $\mathrm{E}$ and $\mathrm{C}$ supplementation. IJERPH. (2020) 17:8452. doi: 10.3390/ijerph17228452

64. Wang L, Chen Q, Zhuang S, Wen Y, Cheng W, Zeng Z, et al. Effect of Anoectochilus roxburghii flavonoids extract on $\mathrm{H} 2 \mathrm{O} 2$ - induced oxidative stress in LO2 cells and D-gal induced aging mice model. $J$ Ethnopharmacol. (2020) 254:112670. doi: 10.1016/j.jep.2020.11 2670

65. Bustos PS, Deza-Ponzio R, Páez PL, Cabrera JL, Virgolini MB, Ortega MG. Flavonoids as protective agents against oxidative stress induced by gentamicin in systemic circulation. Potent protective activity and microbial synergism of luteolin. Food Chem Toxicol. (2018) 118:294302. doi: $10.1016 /$ j.fct.2018.05.030

66. Fukai T, Ushio-Fukai M. Superoxide dismutases: role in redox signaling, vascular function, and diseases. Antioxid Redox Signal. (2011) 15:1583606. doi: 10.1089 /ars.2011.3999

67. Brigelius-Flohé R, Maiorino M. Glutathione peroxidases. Biochim Biophys Acta. (2013) 1830:3289-303. doi: 10.1016/j.bbagen.2012.11.020
68. Bjørklund G, Kern JK, Urbina MA, Saad K, El-Houfey AA, Geier DA, et al. Cerebral hypoperfusion in autism spectrum disorder. Acta Neurobiol Exp. (2018) 78:21-9. doi: 10.21307/ane-2018-005

69. Russo FB, Freitas BC, Pignatari GC, Fernandes IR, Sebat J, Muotri AR, et al. Modeling the interplay between neurons and astrocytes in autism using human induced pluripotent stem cells. Biol Psychiatry. (2018) 83:56978. doi: 10.1016/j.biopsych.2017.09.021

70. Taetzsch T, Levesque S, McGraw C, Brookins S, Luqa R, Bonini MG, et al. Redox regulation of NF-КB p50 and M1 polarization in microglia. Glia. (2015) 63:423-40. doi: 10.1002/glia.22762

71. El-Ansary A, Bjørklund G, Khemakhem AM, Al-Ayadhi L, Chirumbolo S, Ben Bacha A. Metabolism-Associated markers and childhood autism rating scales (CARS) as a measure of autism severity. J Mol Neurosci. (2018) 65:265-76. doi: 10.1007/s12031-018-1091-5

72. De La Fuente M, Miquel J, Catalán MP, Víctor VM, Guayerbas N. The amount of thiolic antioxidant ingestion needed to improve several immune functions is higher in aged than in adult mice. Free Radic Res. (2002) 36:119-26. doi: 10.1080/10715760290006439

73. Finkel T, Holbrook NJ. Oxidants, oxidative stress and the biology of ageing. Nature. (2000) 408:239-47. doi: 10.1038/35041687

74. Andreone BJ, Lacoste B, Gu C. Neuronal and vascular interactions. Annu Rev Neurosci. (2015) 38:25-46. doi: 10.1146/annurev-neuro-071714-033835

75. Ikonomidou C, Kaindl AM. Neuronal death and oxidative stress in the developing brain. Antioxid Redox Signal. (2011) 14:1535-50. doi: 10.1089/ars.2010.3581

76. Bjørklund G, Meguid NA, El-Bana MA, Tinkov AA, Saad K, Dadar M, et al. Oxidative stress in autism spectrum disorder. Mol Neurobiol. (2020) 57:2314-32. doi: 10.1007/s12035-019-01742-2

77. Chauhan A, Gu F, Essa MM, Wegiel J, Kaur K, Brown WT, et al. Brain region-specific deficit in mitochondrial electron transport chain complexes in children with autism. J Neurochem. (2011) 117:20920. doi: 10.1111/j.1471-4159.2011.07189.x

78. Chauhan A, Chauhan V, Brown WT, Cohen I. Oxidative stress in autism: increased lipid peroxidation and reduced serum levels of ceruloplasmin and transferrin-the antioxidant proteins. Life Sci. (2004) 75:253949. doi: $10.1016 /$ j.lfs. 2004.04 .038

79. Fatemi SH, Aldinger KA, Ashwood P, Bauman ML, Blaha CD, Blatt GJ, et al. Consensus paper: pathological role of the cerebellum in autism. Cerebellum. (2012) 11:777-807. doi: 10.1007/s12311-012-0355-9

80. Uchida K, Shiraishi M, Naito Y, Torii Y, Nakamura Y, Osawa T. Activation of stress signaling pathways by the end product of lipid peroxidation. 4-hydroxy-2-nonenal is a potential inducer of intracellular peroxide production. J Biol Chem. (1999) 274:2234-42. doi: 10.1074/jbc.274.4.2234

81. Parola M, Bellomo G, Robino G, Barrera G, Dianzani MU. 4Hydroxynonenal as a biological signal: molecular basis and pathophysiological implications. Antioxid Redox Signal. (1999) 1:255-84. doi: 10.1089/ars.1999.1.3-255

82. Vargas DL, Nascimbene C, Krishnan C, Zimmerman AW, Pardo CA. Neuroglial activation and neuroinflammation in the brain of patients with autism. Ann Neurol. (2005) 57:67-81. doi: 10.1002/ana.20315

83. Prata J, Machado AS, von Doellinger O, Almeida MI, Barbosa MA, Coelho R, et al. The contribution of inflammation to autism spectrum disorders: recent clinical evidence. Methods Mol Biol. (2019) 2011:493510. doi: 10.1007/978-1-4939-9554-7_29

84. Rossignol DA, Frye RE. Evidence linking oxidative stress, mitochondrial dysfunction, and inflammation in the brain of individuals with autism. Front Physiol. (2014) 5:150. doi: 10.3389/fphys.2014.00150

85. López-Hurtado, Edith, Prieto, Jorge, J. A microscopic study of languagerelated cortex in autism. Am J Biochem Biotechnol. (2008). Available online at: http://search.ebscohost.com/login.aspx?direct=true\&db=aph\&AN= 31872240\&site=ehost-live (accessed January 2, 2022).

86. Nadeem A, Ahmad SF, Bakheet SA, Al-Harbi NO, Al-Ayadhi LY, Attia SM, et al. Toll-like receptor 4 signaling is associated with upregulated NADPH oxidase expression in peripheral T cells of children with autism. Brain Behav Immun. (2017) 61:146-54. doi: 10.1016/j.bbi.2016.12.024

87. Nadeem A, Ahmad SF, Al-Harbi NO, Alasmari AF, AL-Ayadhi LY, Alasmari F, et al. Upregulation of enzymatic antioxidants in CD4+ T cells of autistic children. Biochimie. (2020) 171-2:205-12. doi: 10.1016/j.biochi.2020.03.009 
88. Al-Harbi NO, Nadeem A, Ahmad SF, AL-Ayadhi LY, Al-Harbi MM, As Sobeai HM, et al. Elevated expression of toll-like receptor 4 is associated with NADPH oxidase-induced oxidative stress in B cells of children with autism. Int Immunopharmacol. (2020) 84:106555. doi: 10.1016/j.intimp.2020.106555

89. Nadeem A, Ahmad SF, Attia SM, Bakheet SA, Al-Harbi NO, AL-Ayadhi LY. Activation of IL-17 receptor leads to increased oxidative inflammation in peripheral monocytes of autistic children. Brain Behav Immunity. (2018) 67:335-44. doi: 10.1016/j.bbi.2017.09.010

90. Nadeem A, Ahmad SF, Attia SM, AL-Ayadhi LY, Al-Harbi NO, Bakheet SA. Dysregulated enzymatic antioxidant network in peripheral neutrophils and monocytes in children with autism. Prog Neuro Psychopharmacol Biol Psychiatry. (2019) 88:352-9. doi: 10.1016/j.pnpbp.2018.08.020

91. Attia SM, Al-Hamamah MA, Ahmad SF, Nadeem A, Attia MSM, Ansari MA, et al. Evaluation of DNA repair efficiency in autistic children by molecular cytogenetic analysis and transcriptome profiling. DNA Repair. (2020) 85:102750. doi: 10.1016/j.dnarep.2019.102750

92. Pisoschi AM, Pop A. The role of antioxidants in the chemistry of oxidative stress: a review. Euro J Med Chem. (2015) 97:55-74. doi: 10.1016/j.ejmech.2015.04.040

93. Tabaei S, Tabaee SS. DNA methylation abnormalities in atherosclerosis. Artif Cells Nanomed Biotechnol. (2019) 47:203141. doi: 10.1080/21691401.2019.1617724

94. Grafodatskaya D, Chung B, Szatmari P, Weksberg R. Autism spectrum disorders and epigenetics. J Am Acad Child Adolesc Psychiatry. (2010) 49:794-809. doi: 10.1016/j.jaac.2010.05.005

95. Kałuzna-Czaplińska J, Józwik-Pruska J. Chromatographic and mass spectrometric techniques in studies on oxidative stress in autism. J Chromatogr B. (2016) 1019:4-14. doi: 10.1016/j.jchromb.2015.12.035

96. Varghese M, Keshav N, Jacot-Descombes S, Warda T, Wicinski B, Dickstein DL, et al. Autism spectrum disorder: neuropathology and animal models. Acta Neuropathol. (2017) 134:537-66. doi: 10.1007/s00401-017-1736-4

97. Meyyazhagan A, Balasubramanian B, Easwaran M, Alagamuthu KK, Shanmugam S, Kuchi Bhotla H, et al. Biomarker study of the biological parameter and neurotransmitter levels in autistics. Mol Cell Biochem. (2020) 474:277-84. doi: 10.1007/s11010-020-03851-2

98. El-Ansary A, Hassan WM, Daghestani M, Al-Ayadhi L, Ben Bacha A. Preliminary evaluation of a novel nine-biomarker profile for the prediction of autism spectrum disorder. PLOS ONE. (2020) 15:e0227626. doi: 10.1371/journal.pone.0227626

99. Hamed NO, Laila-Al-Ayadhi, Osman MA, Elkhawad AO, Bjørklund G, Qasem $\mathrm{H}$, et al. Determination of neuroinflammatory biomarkers in autistic and neurotypical Saudi children. Metab Brain Dis. (2019) 34:104960. doi: 10.1007/s11011-019-00420-5

100. Hassan MH, Desoky T, Sakhr HM, Gabra RH, Bakri AH. Possible metabolic alterations among autistic male children: clinical and biochemical approaches. J Mol Neurosci. (2019) 67:204-16. doi: 10.1007/s12031-018-1225-9

101. Faber S, Fahrenholz T, Wolle MM, Kern JC, Pamuku M, Miller L, et al. Chronic exposure to xenobiotic pollution leads to significantly higher total glutathione and lower reduced to oxidized glutathione ratio in red blood cells of children with autism. Free Radic Biol Med. (2019) 134:66677. doi: 10.1016/j.freeradbiomed.2019.02.009

102. El-Ansary A, Cannell JJ, Bjørklund G, Bhat RS, Al Dbass AM, Alfawaz $\mathrm{HA}$, et al. In the search for reliable biomarkers for the early diagnosis of autism spectrum disorder: the role of vitamin D. Metab Brain Dis. (2018) 33:917-31. doi: 10.1007/s11011-018-0199-1

103. Howsmon DP, Kruger U, Melnyk S, James SJ, Hahn J. Classification and adaptive behavior prediction of children with autism spectrum disorder based upon multivariate data analysis of markers of oxidative stress and DNA methylation. PLoS Comput Biol. (2017) 13:e1005385. doi: 10.1371/journal.pcbi.1005385

104. Meguid NA, Ghozlan SAS, Mohamed MF, Ibrahim MK, Dawood RM, Bader El Din NG, et al. Expression of reactive oxygen species-related transcripts in Egyptian children with autism. Biomark Insights. (2017) 12:117727191769103. doi: 10.1177/1177271917691035

105. Khemakhem AM, Frye RE, El-Ansary A, Al-Ayadhi L, Bacha AB. Novel biomarkers of metabolic dysfunction is autism spectrum disorder: potential for biological diagnostic markers. Metab Brain Dis. (2017) 32:198397. doi: 10.1007/s11011-017-0085-2

106. El-Ansary A, Bjørklund G, Chirumbolo S, Alnakhli OM. Predictive value of selected biomarkers related to metabolism and oxidative stress in children with autism spectrum disorder. Metab Brain Dis. (2017) 32:120921. doi: 10.1007/s11011-017-0029-x

107. Signorini C, De Felice C, Durand T, Galano J-M, Oger C, Leoncini $\mathrm{S}$, et al. Relevance of 4-F4t-neuroprostane and 10-F4tneuroprostane to neurological diseases. Free Radic Biol Med. (2018) 115:278-87. doi: 10.1016/j.freeradbiomed.2017.12.009

108. Metwally FM, Rashad H, Zeidan HM, Kilany A, Abdol Raouf ER. Study of the effect of bisphenol a on oxidative stress in children with autism spectrum disorders. Ind J Clin Biochem. (2018) 33:196201. doi: 10.1007/s12291-017-0667-0

109. El-Ansary A. Data of multiple regressions analysis between selected biomarkers related to glutamate excitotoxicity and oxidative stress in Saudi autistic patients. Data Brief. (2016) 7:111-6. doi: 10.1016/j.dib.2016.02.025

110. Qasem H, Al-Ayadhi L, El-Ansary A. Cysteinyl leukotriene correlated with 8 -isoprostane levels as predictive biomarkers for sensory dysfunction in autism. Lipids Health Dis. (2016) 15:130. doi: 10.1186/s12944-016-0298-0

111. Cortelazzo A, De Felice C, Guerranti R, Signorini C, Leoncini S, Zollo G, et al. Expression and oxidative modifications of plasma proteins in autism spectrum disorders: interplay between inflammatory response and lipid peroxidation. Proteomics. (2016) 10:1103-12. doi: 10.1002/prca.201500076

112. Ciccoli L, De Felice C, Paccagnini E, Leoncini S, Pecorelli A, Signorini C, et al. Erythrocyte shape abnormalities, membrane oxidative damage, and $\beta$-actin alterations: an unrecognized triad in classical autism. Med Inflamm. (2013) 2013:432616. doi: 10.1155/2013/432616

113. Gorrindo P, Lane CJ, Lee EB, McLaughlin B, Levitt P. Enrichment of elevated plasma F2t-isoprostane levels in individuals with autism who are stratified by presence of gastrointestinal dysfunction. PLoS ONE. (2013) 8:e68444. doi: 10.1371/journal.pone.0068444

114. Frye RE, DeLaTorre R, Taylor H, Slattery J, Melnyk S, Chowdhury $\mathrm{N}$, et al. Redox metabolism abnormalities in autistic children associated with mitochondrial disease. Transl Psychiatry. (2013) 3:e273-e273. doi: 10.1038/tp.2013.51

115. El-Ansary A, Al-Ayadhi L. Lipid mediators in plasma of autism spectrum disorders. Lipids Health Dis. (2012) 11:160. doi: 10.1186/1476-511X-11-160

116. Melnyk S, Fuchs GJ, Schulz E, Lopez M, Kahler SG, Fussell JJ, et al. Metabolic imbalance associated with methylation dysregulation and oxidative damage in children with autism. J Autism Dev Disord. (2012) 42:367-77. doi: 10.1007/s10803-011-1260-7

117. Essa M, Guillemin G, Hakkim F, Waly M, Al-Farsi Y, Al-Shafaee M, et al. Reduced levels of antioxidant proteins in children with autism in Oman. Int J Nutr Pharmacol Neurol Dis. (2012) 2:53. doi: 10.4103/2231-0738.93136

118. Lakshmi Priya MD, Geetha A. A biochemical study on the level of proteins and their percentage of nitration in the hair and nail of autistic children. Clin Chim Acta. (2011) 412:1036-1042. doi: 10.1016/j.cca.2011.02.021

119. Essa MM, Guillemin GJ, Waly MI, Al-Sharbati MM, Al-Farsi YM, Hakkim FL, et al. Increased markers of oxidative stress in autistic children of the sultanate of oman. Biol Trace Elem Res. (2012) 147:257. doi: 10.1007/s12011-011-9280-x

120. Rose S, Melnyk S, Trusty TA, Pavliv O, Seidel L, Li J, et al. Intracellular and extracellular redox status and free radical generation in primary immune cells from children with autism. Autism Res Treatment. (2012) 2012:110. doi: 10.1155/2012/986519

121. Al-Yafee YA, Al- Ayadhi LY, Haq SH, El-Ansary AK. Novel metabolic biomarkers related to sulfur-dependent detoxification pathways in autistic patients of Saudi Arabia. BMC Neurol. (2011) 11:139. doi: 10.1186/1471-2377-11-139

122. Adams JB, Audhya T, McDonough-Means S, Rubin RA, Quig D, Geis E, et al. Nutritional and metabolic status of children with autism vs. neurotypical children, and the association with autism severity. Nutr Metab. (2011) 8:34. doi: 10.1186/1743-7075-8-34

123. El-Ansary AK, Ben Bacha AG, Al- Ayahdi LY. Plasma fatty acids as diagnostic markers in autistic patients from Saudi Arabia. Lipids Health Dis. (2011) 10:62. doi: 10.1186/1476-511X-10-62 
124. El-Ansary AK, Ben Bacha AG, Al- Ayahdi LY. Impaired plasma phospholipids and relative amounts of essential polyunsaturated fatty acids in autistic patients from Saudi Arabia. Lipids Health Dis. (2011) 10:63. doi: 10.1186/1476-511X-10-63

125. Ali A, Waly MI, Al-Farsi YM, Essa MM, Al-Sharbati MM, Deth RC. Hyperhomocysteinemia among omani autistic children: a case-control study. Acta Biochim Pol. (2011) 58:547-51. doi: 10.18388/abp.2011_2223

126. AL-ayadhi LY, Mostafa GA. Increased serum osteopontin levels in autistic children: relation to the disease severity. Brain Behav Immunity. (2011) 25:1393-8. doi: 10.1016/j.bbi.2011.04.006

127. Khakzad MR, Javanbakht M, Shayegan MR, Kianoush S, Omid F, Hojati M, et al. The complementary role of high sensitivity C-reactive protein in the diagnosis and severity assessment of autism. Res Autism Spect Disord. (2012) 6:1032-7. doi: 10.1016/j.rasd.2011.10.002

128. Meguid NA, Dardir AA, Abdel-Raouf ER, Hashish A. Evaluation of oxidative stress in autism: defective antioxidant enzymes and increased lipid peroxidation. Biol Trace Elem Res. (2011) 143:58-65. doi: 10.1007/s12011-010-8840-9

129. Ming X, Johnson WG, Stenroos ES, Mars A, Lambert GH, Buyske S. Genetic variant of glutathione peroxidase 1 in autism. Brain Dev. (2010) 32:1059. doi: 10.1016/j.braindev.2008.12.017

130. Osredkar J, Gosar D, Maček J, Kumer K, Fabjan T, Finderle P, et al. Urinary markers of oxidative stress in children with autism spectrum disorder (ASD). Antioxidants. (2019) 8:187. doi: 10.3390/antiox8060187

131. Yui K, Tanuma N, Yamada H, Kawasaki Y. Decreased total antioxidant capacity has a larger effect size than increased oxidant levels in urine in individuals with autism spectrum disorder. Environ Sci Pollut Res. (2017) 24:9635-44. doi: 10.1007/s11356-017-8595-3

132. Puig-Alcaraz C, Fuentes-Albero M, Calderón J, Garrote D, Cauli O. Increased homocysteine levels correlate with the communication deficit in children with autism spectrum disorder. Psychiatry Res. (2015) 229:10317. doi: 10.1016/j.psychres.2015.05.021

133. Ranjbar A, Rashedi V, Rezaei M. Comparison of urinary oxidative biomarkers in Iranian children with autism. Res Dev Disabil. (2014) 35:27515. doi: 10.1016/j.ridd.2014.07.010

134. Kałuzna-Czaplińska J, Michalska M, Rynkowski J. Homocysteine level in urine of autistic and healthy children. Acta Biochim Pol. (2011) 58:314. doi: 10.18388/abp.2011_2281

135. Kałuzna-Czaplińska J. Noninvasive urinary organic acids test to assess biochemical and nutritional individuality in autistic children. Clin Biochem. (2011) 44:686-691. doi: 10.1016/j.clinbiochem.2011.01.015

136. Damodaran LPM, Arumugam G. Urinary oxidative stress markers in children with autism. Redox Rep. (2011) 16:21622. doi: 10.1179/1351000211Y.0000000012

137. Youn S-I, Jin S-H, Kim S-H, Lim S. Porphyrinuria in Korean children with autism: correlation with oxidative stress. J Toxicol Environ Health. (2010) 73:701-10. doi: 10.1080/15287391003614000

138. Ngounou Wetie AG, Wormwood KL, Charette L, Ryan JP, Woods AG, Darie CC. Comparative two-dimensional polyacrylamide gel electrophoresis of the salivary proteome of children with autism spectrum disorder. J Cell Mol Med. (2015) 19:2664-78. doi: 10.1111/jcmm.12658

139. Anwar A, Abruzzo PM, Pasha S, Rajpoot K, Bolotta A, Ghezzo A, et al. Advanced glycation endproducts, dityrosine and arginine transporter dysfunction in autism - a source of biomarkers for clinical diagnosis. $\mathrm{Mol}$ Autism. (2018) 9:3. doi: 10.1186/s13229-017-0183-3

140. Yenkoyan K, Harutyunyan H, Harutyunyan A. A certain role of SOD/CAT imbalance in pathogenesis of autism spectrum disorders. Free Radic Biol Med. (2018) 123:85-95. doi: 10.1016/j.freeradbiomed.2018.05.070

141. Boris M, Goldblatt A, Galanko J, James S. Association of MTHFR gene variants with autism. J Am Phys Surg. (2004) 9:106-8.

142. James SJ, Melnyk S, Jernigan S, Cleves MA, Halsted CH, Wong DH, et al. Metabolic endophenotype and related genotypes are associated with oxidative stress in children with autism. Am J Med Genet B Neuropsychiatr Genet. (2006) 141B:947-56. doi: 10.1002/ajmg.b. 30366

143. Bowers K, Li Q, Bressler J, Avramopoulos D, Newschaffer C, Fallin MD. Glutathione pathway gene variation and risk of autism spectrum disorders. $J$ Neurodevelop Disord. (2011) 3:132-43. doi: 10.1007/s11689-011-9077-4
144. Frustaci A, Neri M, Cesario A, Adams JB, Domenici E, Dalla Bernardina B, et al. Oxidative stress-related biomarkers in autism: systematic review and meta-analyses. Free Radic Biol Med. (2012) 52:2128-41. doi: 10.1016/j.freeradbiomed.2012.03.011

145. Goin-Kochel RP, Porter AE, Peters SU, Shinawi M, Sahoo T, Beaudet al. The MTHFR 677C->T polymorphism and behaviors in children with autism: exploratory genotype-phenotype correlations. Autism Res. (2009) 2:98-108. doi: 10.1002/aur.70

146. Guo T, Chen H, Liu B, Ji W, Yang C. Methylenetetrahydrofolate reductase polymorphisms C677T and risk of autism in the Chinese han population. Genet Test Mol Biomark. (2012) 16:968-73. doi: 10.1089/gtmb.2012.0091

147. Chen L, Shi X-J, Liu H, Mao X, Gui L-N, Wang H, et al. Oxidative stress marker aberrations in children with autism spectrum disorder: a systematic review and meta-analysis of 87 studies $(\mathrm{N}=9109)$. Transl Psychiatry. (2021) 11:15. doi: 10.1038/s41398-020-01135-3

148. Adams JB, Baral M, Geis E, Mitchell J, Ingram J, Hensley A, et al. The severity of autism is associated with toxic metal body burden and red blood cell glutathione levels. J Toxicol. (2009) 2009:532640. doi: 10.1155/2009/532640

149. Zhang J, Lin J, Zhao X, Yao F, Feng C, He Z, et al. Trace element changes in the plasma of autism spectrum disorder children and the positive correlation between chromium and vanadium. Biol Trace Elem Res. (2022). doi: 10.1007/ s12011-021-03082-6 [Online ahead of print].

150. Zhao HM, Li RH. Progress in the research of GSH in cells. Chin Sci Bull. (2011) 56:3057. doi: 10.1007/s11434-011-4689-3

151. Carocci A, Rovito N, Sinicropi MS, Genchi G. Mercury Toxicity and Neurodegenerative Effects. In: Whitacre DM, editor. Reviews of Environmental Contamination and Toxicology. Reviews of Environmental Contamination and Toxicology. Cham: Springer International Publishing (2014). p. 1-18 doi: 10.1007/978-3-319-03777-6_1

152. Ghanizadeh A, Akhondzadeh S, Hormozi M, Makarem A, Abotorabi-Zarchi M, Firoozabadi A. Glutathione-related factors and oxidative stress in autism, a review. Curr Med Chem. (2012) 19:4000-5. doi: 10.2174/092986712802002572

153. Gu F, Chauhan V, Chauhan A. Glutathione redox imbalance in brain disorders. Curr Opin Clin Nutr Metab Care. (2015) 18:89-95. doi: 10.1097/MCO.0000000000000134

154. Lu SC. Glutathione synthesis. Biochim Biophys Acta. (2013) 1830:314353. doi: 10.1016/j.bbagen.2012.09.008

155. Guo B-Q, Li H-B, Ding S-B. Blood homocysteine levels in children with autism spectrum disorder: an updated systematic review and meta-analysis. Psychiatry Res. (2020) 291:113283. doi: 10.1016/j.psychres.2020.113283

156. Cai J, Ding L, Zhang J-S, Xue J, Wang L-Z. Elevated plasma levels of glutamate in children with autism spectrum disorders. Neuroreport. (2016) 27:272-6. doi: 10.1097/WNR.0000000000000532

157. Wang L, Jia J, Zhang J, Li K. Serum levels of SOD and risk of autism spectrum disorder: a case-control study. Int J Dev Neurosci. (2016) 51:126. doi: 10.1016/j.ijdevneu.2016.04.004

158. James SJ, Cutler P, Melnyk S, Jernigan S, Janak L, Gaylor DW, et al. Metabolic biomarkers of increased oxidative stress and impaired methylation capacity in children with autism. Am J Clin Nutr. (2004) 80:16117. doi: 10.1093/ajcn/80.6.1611

159. Adams M, Lucock M, Stuart J, Fardell S, Baker K, Ng X. Preliminary evidence for involvement of the folate gene polymorphism 19bp deletion-DHFR in occurrence of autism. Neurosci Lett. (2007) 422:24-9. doi: 10.1016/j.neulet.2007.05.025

160. Main PAE, Thomas P, Angley MT, Young R, Esterman A, King CE, et al. Lack of evidence for genomic instability in autistic children as measured by the cytokinesis-block micronucleus cytome assay. Autism Res. (2015) 8:94-104. doi: 10.1002/aur.1428

161. Yektaş Ç, Alpay M, Tufan AE. Comparison of serum B12, folate and homocysteine concentrations in children with autism spectrum disorder or attention deficit hyperactivity disorder and healthy controls. Neuropsychiatr Dis Treat. (2019) 15:2213-9. doi: 10.2147/NDT.S212361

162. Ladd-Acosta C, Hansen KD, Briem E, Fallin MD, Kaufmann WE, Feinberg AP. Common DNA methylation alterations in multiple brain regions in autism. Mol Psychiatry. (2014) 19:862-71. doi: 10.1038/mp.2013.114

163. Stanger O, Fowler B, Piertzik K, Huemer M, Haschke-Becher E, Semmler A, et al. Homocysteine, folate and vitamin B12 in neuropsychiatric diseases: 
review and treatment recommendations. Expert Rev Neurother. (2009) 9:1393-412. doi: 10.1586/ern.09.75

164. Bala KA, Dogan M, Kaba S, Mutluer T, Aslan O, Dogan SZ. Hormone disorder and vitamin deficiency in attention deficit hyperactivity disorder (ADHD) and autism spectrum disorders (ASDs). J Pediatr Endocrinol Metab. (2016) 29:1077-82. doi: 10.1515/jpem-2015-0473

165. Fuentes-Albero M, Cauli O. Homocysteine levels in autism spectrum disorder: a clinical update. Endocr Metab Immune Disord Drug Targets. (2018) 18:289-96. doi: 10.2174/1871530318666180213110815

166. Kałuzna-Czaplińska J, Zurawicz E, Michalska M, Rynkowski J. A focus on homocysteine in autism. Acta Biochim Pol. (2013) 60:13742. doi: 10.18388/abp.2013_1963

167. Zhang Y, Hodgson NW, Trivedi MS, Abdolmaleky HM, Fournier M, Cuenod M, et al. Decreased brain levels of vitamin B12 in aging, autism and schizophrenia. PLoS ONE. (2016) 11:e0146797. doi: 10.1371/journal.pone.0146797

168. Gevi F, Belardo A, Zolla L. A metabolomics approach to investigate urine levels of neurotransmitters and related metabolites in autistic children. Biochim Biophys Acta Mol Basis Dis. (2020) 1866:165859. doi: 10.1016/j.bbadis.2020.165859

169. Lipton SA, Kim WK, Choi YB, Kumar S, D’Emilia DM, Rayudu PV, et al. Neurotoxicity associated with dual actions of homocysteine at the N-methyl-D-aspartate receptor. Proc Natl Acad Sci USA. (1997) 94:59238. doi: 10.1073 /pnas.94.11.5923

170. Mattson MP, Shea TB. Folate and homocysteine metabolism in neural plasticity and neurodegenerative disorders. Trends Neurosci. (2003) 26:13746. doi: 10.1016/S0166-2236(03)00032-8

171. Ayala A, Muñoz MF, Argüelles S. Lipid peroxidation: production, metabolism, and signaling mechanisms of malondialdehyde and 4-hydroxy-2-nonenal. Oxid Med Cell Longev. (2014) 2014:360438. doi: 10.1155/2014/360438

172. Anzai K, Ogawa K, Goto Y, Senzaki Y, Ozawa T, Yamamoto H. Oxidationdependent changes in the stability and permeability of lipid bilayers. Antioxid Redox Signal. (1999) 1:339-47. doi: 10.1089/ars.1999.1.3-339

173. Yehuda S, Rabinovitz S, Carasso RL, Mostofsky DI. The role of polyunsaturated fatty acids in restoring the aging neuronal membrane. Neurobiol Aging. (2002) 23:843-53. doi: 10.1016/S0197-4580(02)00074-X

174. Massey KA, Nicolaou A. Lipidomics of polyunsaturated-fattyacid-derived oxygenated metabolites. Biochem Soc Trans. (2011) 39:1240-6. doi: 10.1042/BST0391240

175. Massey KA, Nicolaou A. Lipidomics of oxidized polyunsaturated fatty acids. Free Radic Biol Med. (2013) 59:45-55. doi: 10.1016/j.freeradbiomed.2012.08.565

176. Jornayvaz FR, Shulman GI. Diacylglycerol activation of protein kinase $C \varepsilon$ and hepatic insulin resistance. Cell Metab. (2012) 15:574-84. doi: 10.1016/j.cmet.2012.03.005

177. Giorgi C, Agnoletto C, Baldini C, Bononi A, Bonora M, Marchi S, et al. Redox control of protein kinase C: cell- and disease-specific aspects. Antioxid Redox Signal. (2010) 13:1051-85. doi: 10.1089/ars.2009.2825

178. Yang C, Kazanietz MG. Chimaerins: GAPs that bridge diacylglycerol signalling and the small G-protein Rac. Biochem J. (2007) 403:112. doi: $10.1042 / B J 20061750$

179. Baumann J, Sevinsky C, Conklin DS. Lipid biology of breast cancer. Biochim Biophys Acta. (2013) 1831:1509-17. doi: 10.1016/j.bbalip.2013.03.011

180. Fisher SK, Novak JE, Agranoff BW. Inositol and higher inositol phosphates in neural tissues: homeostasis, metabolism and functional significance. J Neurochem. (2002) 82:736-54. doi: 10.1046/j.1471-4159.2002.01 041.x

181. Conway SJ, Miller GJ. Biology-enabling inositol phosphates, phosphatidylinositol phosphates and derivatives. Nat Prod Rep. (2007) 24:687-707. doi: 10.1039/b407701f

182. Aoki T, Narumiya S. Prostaglandins and chronic inflammation. Trends Pharmacol Sci. (2012) 33:304-11. doi: 10.1016/j.tips.2012.02.004

183. Tang EHC, Libby P, Vanhoutte PM, Xu A. Anti-inflammation therapy by activation of prostaglandin EP4 receptor in cardiovascular and other inflammatory diseases. J Cardiovasc Pharmacol. (2012) 59:11623. doi: 10.1097/FJC.0b013e3182244a12
184. Kalinski P. Regulation of immune responses by prostaglandin E2. J Immunol. (2012) 188:21-8. doi: 10.4049/jimmunol.1101029

185. Pluchino N, Russo M, Santoro AN, Litta P, Cela V, Genazzani AR. Steroid hormones and BDNF. Neuroscience. (2013) 239:2719. doi: 10.1016/j.neuroscience.2013.01.025

186. Frackowiak J, Mazur-Kolecka B, Schanen NC, Brown WT, Wegiel J. The link between intraneuronal $\mathrm{N}$-truncated amyloid- $\beta$ peptide and oxidatively modified lipids in idiopathic autism and dup(15q11.2-q13)/autism. Acta Neuropathol Commun. (2013) 1:61. doi: 10.1186/2051-5960-1-61

187. Wang X, Lei XG, Wang J. Malondialdehyde regulates glucosestimulated insulin secretion in murine islets via TCF7L2dependent Wnt signaling pathway. Mol Cell Endocrinol. (2014) 382:8-16. doi: 10.1016/j.mce.2013.09.003

188. García-Ruiz I, de la Torre P, Díaz T, Esteban E, Fernández I, Muñoz-Yagüe $\mathrm{T}$, et al. Sp1 and Sp3 transcription factors mediate malondialdehyde-induced collagen alpha 1(I) gene expression in cultured hepatic stellate cells. J Biol Chem. (2002) 277:30551-8. doi: 10.1074/jbc.M203368200

189. Negre-Salvayre A, Coatrieux C, Ingueneau C, Salvayre R. Advanced lipid peroxidation end products in oxidative damage to proteins. Potential role in diseases and therapeutic prospects for the inhibitors. Br J Pharmacol. (2008) 153:6-20. doi: 10.1038/sj.bjp.0707395

190. Pizzimenti S, Ciamporcero E, Daga M, Pettazzoni P, Arcaro A, Cetrangolo G, et al. Interaction of aldehydes derived from lipid peroxidation and membrane proteins. Front Physiol. (2013) 4:242. doi: 10.3389/fphys.2013.00242

191. Slatter DA, Avery NC, Bailey AJ. Identification of a new cross-link and unique histidine adduct from bovine serum albumin incubated with malondialdehyde. J Biol Chem. (2004) 279:61-69. doi: 10.1074/jbc.M310608200

192. Cheng J, Wang F, Yu D-F, Wu P-F, Chen J-G. The cytotoxic mechanism of malondialdehyde and protective effect of carnosine via protein cross-linking/mitochondrial dysfunction/reactive oxygen species/MAPK pathway in neurons. Eur J Pharmacol. (2011) 650:184-94. doi: 10.1016/j.ejphar.2010.09.033

193. Niedernhofer LJ, Daniels JS, Rouzer CA, Greene RE, Marnett LJ. Malondialdehyde, a product of lipid peroxidation, is mutagenic in human cells. J Biol Chem. (2003) 278:31426-33. doi: 10.1074/jbc.M212549200

194. VanderVeen LA, Hashim MF, Shyr Y, Marnett LJ. Induction of frameshift and base pair substitution mutations by the major DNA adduct of the endogenous carcinogen malondialdehyde. Proc Natl Acad Sci USA. (2003) 100:14247-52. doi: 10.1073/pnas.2332176100

195. Ji C, Rouzer CA, Marnett LJ, Pietenpol JA. Induction of cell cycle arrest by the endogenous product of lipid peroxidation, malondialdehyde. Carcinogenesis. (1998) 19:1275-83. doi: 10.1093/carcin/19.7.1275

196. László A, Novák Z, Szollosi-Varga I, Hai DQ, Vetró Á, Kovács A. Blood lipid peroxidation, antioxidant enzyme activities and hemorheological changes in autistic children. Ideggyogy Sz. (2013) 66:23-8.

197. Esterbauer H, Cheeseman KH. Determination of aldehydic lipid peroxidation products: malonaldehyde and 4-hydroxynonenal. Methods Enzymol. (1990) 186:407-21. doi: 10.1016/0076-6879(90) 86134-H

198. Yoden K, Iio T. Determination of thiobarbituric acid-reactive substances in oxidized lipids by high-performance liquid chromatography with a postcolumn reaction system. Anal Biochem. (1989) 182:116-20. doi: 10.1016/0003-2697(89)90727-6

199. Esterbauer H, Schaur RJ, Zollner H. Chemistry and biochemistry of 4hydroxynonenal, malonaldehyde and related aldehydes. Free Radic Biol Med. (1991) 11:81-128. doi: 10.1016/0891-5849(91)90192-6

200. Fujioka K, Shibamoto T. Improved malonaldehyde assay using headspace solid-phase microextraction and its application to the measurement of the antioxidant activity of phytochemicals. J Agric Food Chem. (2005) 53:470813. doi: $10.1021 / \mathrm{jf0} 050297 \mathrm{q}$

201. Maboudou P, Mathieu D, Bachelet H, Wiart JF, Lhermitte M. Detection of oxidative stress. Interest of GC-MS for malondialdehyde and formaldehyde monitoring. Biomed Chromatogr. (2002) 16:199-202. doi: 10.1002/bmc.127

202. McGirr LG, Hadley M, Draper HH. Identification of N alpha-acetyl-epsilon(2-propenal)lysine as a urinary metabolite of malondialdehyde. J Biol Chem. (1985) 260:15427-31. doi: 10.1016/S0021-9258(17)36271-3 
203. Draper HH, Hadley M, Lissemore L, Laing NM, Cole PD. Identification of N-epsilon-(2-propenal)lysine as a major urinary metabolite of malondialdehyde. Lipids. (1988) 23:626-8. doi: 10.1007/BF02535610

204. Hadley $M$, Draper HH. Identification of $\mathrm{N}$-(2-propenal) serine as a urinary metabolite of malondialdehyde. FASEB J. (1988) 2:13840. doi: 10.1096/fasebj.2.2.3125082

205. Hadley M, Draper HH. Identification of N-(2-propenal)ethanolamine as a urinary metabolite of malondialdehyde. Free Radic Biol Med. (1989) 6:4952. doi: 10.1016/0891-5849(89)90159-7

206. Huang Y, Li W, Kong A-NT. Anti-oxidative stress regulator NF-E2-related factor 2 mediates the adaptive induction of antioxidant and detoxifying enzymes by lipid peroxidation metabolite 4-hydroxynonenal. Cell Biosci. (2012) 2:40. doi: 10.1186/2045-3701-2-40

207. Siow RCM, Ishii T, Mann GE. Modulation of antioxidant gene expression by 4-hydroxynonenal: atheroprotective role of the Nrf2/ARE transcription pathway. Redox Rep. (2007) 12:11-5. doi: 10.1179/135100007X162167

208. Forman HJ, Dickinson DA, Iles KE. HNE-signaling pathways leading to its elimination. Mol Aspects Med. (2003) 24:18994. doi: 10.1016/S0098-2997(03)00013-X

209. Ahmadian M, Suh JM, Hah N, Liddle C, Atkins AR, Downes M, et al. PPAR $\gamma$ signaling and metabolism: the good, the bad and the future. Nat Med. (2013) 19:557-66. doi: 10.1038/nm.3159

210. Barrera G, Toaldo C, Pizzimenti S, Cerbone A, Pettazzoni P, Dianzani MU, et al. The role of ppar ligands in controlling growth-related gene expression and their interaction with lipoperoxidation products. PPAR Res. (2008) 2008:524671. doi: 10.1155/2008/524671

211. Dalleau S, Baradat M, Guéraud F, Huc L. Cell death and diseases related to oxidative stress: 4-hydroxynonenal (HNE) in the balance. Cell Death Differ. (2013) 20:1615-30. doi: 10.1038/cdd.2013.138

212. Fritz KS, Petersen DR. Exploring the biology of lipid peroxidationderived protein carbonylation. Chem Res Toxicol. (2011) 24:14119. doi: $10.1021 / \mathrm{tx} 200169 \mathrm{n}$

213. Eckl PM. Genotoxicity of HNE. Mol Aspects Med. (2003) 24:1615. doi: 10.1016/S0098-2997(03)00010-4

214. Haberzettl P, Hill BG. Oxidized lipids activate autophagy in a JNK-dependent manner by stimulating the endoplasmic reticulum stress response. Redox Biol. (2013) 1:56-64. doi: 10.1016/ j.redox.2012.10.003

215. Dodson M, Liang Q, Johnson MS, Redmann M, Fineberg N, DarleyUsmar VM, et al. Inhibition of glycolysis attenuates 4-hydroxynonenaldependent autophagy and exacerbates apoptosis in differentiated SH-SY5Y neuroblastoma cells. Autophagy. (2013) 9:1996-2008. doi: 10.4161/auto. 26094

216. Awasthi YC, Sharma R, Sharma A, Yadav S, Singhal SS, Chaudhary P, et al. Self-regulatory role of 4-hydroxynonenal in signaling for stressinduced programmed cell death. Free Radic Biol Med. (2008) 45:1118. doi: 10.1016/j.freeradbiomed.2008.04.007

217. Chaudhary P, Sharma R, Sharma A, Vatsyayan R, Yadav S, Singhal SS, et al. Mechanisms of 4-hydroxy-2-nonenal induced pro- and antiapoptotic signaling. Biochemistry. (2010) 49:6263-75. doi: 10.1021/ bi100517x

218. Yan L-J, Forster MJ. Chemical probes for analysis of carbonylated proteins: a review. J Chromatogr B Analyt Technol Biomed Life Sci. (2011) 879:13081315. doi: 10.1016/j.jchromb.2010.08.004

219. Jürgens G, Ashy A, Esterbauer H. Detection of new epitopes formed upon oxidation of low-density lipoprotein, lipoprotein (a) and very-lowdensity lipoprotein. Use of an antiserum against 4-hydroxynonenal-modified low-density lipoprotein. Biochem J. (1990) 265:605-8. doi: 10.1042/bj265 0605

220. Chen Q, Esterbauer H, Jürgens G. Studies on epitopes on lowdensity lipoprotein modified by 4-hydroxynonenal. Biochemical characterization and determination. Biochem J. (1992) 288 (Pt. 1):249-54. doi: 10.1042/bj2880249

221. Pecorelli A, Leoncini S, De Felice C, Signorini C, Cerrone C, Valacchi G, et al. Non-protein-bound iron and 4-hydroxynonenal protein adducts in classic autism. Brain Dev. (2013) 35:146-54. doi: 10.1016/j.braindev.2012. 03.011
222. Spickett CM. The lipid peroxidation product 4-hydroxy-2nonenal: advances in chemistry and analysis. Redox Biol. (2013) 1:145-52. doi: 10.1016/j.redox.2013.01.007

223. Dong D, Zielke HR, Yeh D, Yang P. Cellular stress and apoptosis contribute to the pathogenesis of autism spectrum disorder: the role of cellular stress and apoptosis in autism. Autism Res. (2018) 11:107690. doi: 10.1002/aur.1966

224. Anderson NL, Anderson NG. The human plasma proteome: history, character, and diagnostic prospects. Mol Cell Proteomics. (2002) 1:84567. doi: 10.1074/mcp.R200007-MCP200

225. Harpole M, Davis J, Espina V. Current state of the art for enhancing urine biomarker discovery. Expert Rev Proteomics. (2016) 13:60926. doi: 10.1080/14789450.2016.1190651

226. Decramer S, Gonzalez de Peredo A, Breuil B, Mischak H, Monsarrat B, Bascands J-L, et al. Urine in clinical proteomics. Mol Cell Proteomics. (2008) 7:1850-62. doi: 10.1074/mcp.R800001-MCP200

227. Paşca SP, Nemeş B, Vlase L, Gagyi CE, Dronca E, Miu AC, et al. High levels of homocysteine and low serum paraoxonase 1 arylesterase activity in children with autism. Life Sci. (2006) 78:2244-8. doi: 10.1016/j.lfs.2005.09.040

228. Ornoy A, Weinstein-Fudim L, Ergaz Z. Prevention or amelioration of autism-like symptoms in animal models: will it bring Us closer to treating human ASD? Int J Mol Sci. (2019) 20:E1074. doi: 10.3390/ijms20051074

229. Nadeem A, Ahmad SF, Al-Harbi NO, Attia SM, Bakheet SA, Ibrahim $\mathrm{KE}$, et al. Nrf2 activator, sulforaphane ameliorates autism-like symptoms through suppression of Th17 related signaling and rectification of oxidantantioxidant imbalance in periphery and brain of BTBR T+tf/J mice. Behav Brain Res. (2019) 364:213-24. doi: 10.1016/j.bbr.2019.02.031

230. Xie W, Ge X, Li L, Yao A, Wang X, Li M, et al. Resveratrol ameliorates prenatal progestin exposure-induced autism-like behavior through ER $\beta$ activation. Mol Autism. (2018) 9:43. doi: 10.1186/s13229-018-0225-5

231. Ahmad SF, Ansari MA, Nadeem A, Bakheet SA, Alzahrani MZ, Alshammari $\mathrm{MA}$, et al. Resveratrol attenuates pro-inflammatory cytokines and activation of JAK1-STAT3 in BTBR T+ Itpr3tf/J autistic mice. Eur J Pharmacol. (2018) 829:70-8. doi: 10.1016/j.ejphar.2018.04.008

232. Ahmad SF, Ansari MA, Nadeem A, Alzahrani MZ, Bakheet SA, Attia SM. Resveratrol improves neuroimmune dysregulation through the inhibition of neuronal toll-like receptors and COX-2 signaling in BTBR T+ Itpr3tf/J mice. Neuromol Med. (2018) 20:133-46. doi: 10.1007/s12017-018-8483-0

233. Bhandari R, Kuhad A. Resveratrol suppresses neuroinflammation in the experimental paradigm of autism spectrum disorders. Neurochem Int. (2017) 103:8-23. doi: 10.1016/j.neuint.2016.12.012

234. Zhang Y, Cui W, Zhai Q, Zhang T, Wen X. N-acetylcysteine ameliorates repetitive/stereotypic behavior due to its antioxidant properties without activation of the canonical Wnt pathway in a valproic acid-induced rat model of autism. Mol Med Rep. (2017) 16:2233-40. doi: 10.3892/mmr.2017.6787

235. Aldbass AM, Bhat RS, El-Ansary A. Protective and therapeutic potency of $\mathrm{N}$-acetyl-cysteine on propionic acid-induced biochemical autistic features in rats. J Neuroinflammation. (2013) 10:42. doi: 10.1186/1742-2094-10-42

236. Khalaj R, Hajizadeh Moghaddam A, Zare M. Hesperetin and it nanocrystals ameliorate social behavior deficits and oxidoinflammatory stress in rat model of autism. Int J Dev Neurosci. (2018) 69:80-7. doi: 10.1016/j.ijdevneu.2018.06.009

237. Frandsen JR, Narayanasamy P. Neuroprotection through flavonoid: enhancement of the glyoxalase pathway. Redox Biol. (2018) 14:46573. doi: $10.1016 /$ j.redox.2017.10.015

238. Ayyathan DM, Chandrasekaran R, Thiagarajan K. Neuroprotective effect of tagara, an ayurvedic drug against methyl mercury induced oxidative stress using rat brain mitochondrial fractions. BMC Complement Altern Med. (2015) 15:268. doi: 10.1186/s12906-015-0793-2

239. Hamzawy MA, El-Ghandour YB, Abdel-Aziem SH, Ali ZH. Leptin and camel milk abate oxidative stress status, genotoxicity induced in valproic acid rat model of autism. Int J Immunopathol Pharmacol. (2018) 32:2058738418785514. doi: 10.1177/2058738418785514

240. Rani V, Gautam S, Rawat JK, Singh M, Devi U, Yadav RK, et al. Effects of minocycline and doxycycline against terbutaline induced early postnatal autistic changes in albino rats. Physiol Behav. (2018) 183:4956. doi: 10.1016/j.physbeh.2017.10.024 
241. Dominiak A, Wilkaniec A, Jeśko H, Czapski GA, Lenkiewicz AM, Kurek E, et al. Selol, an organic selenium donor, prevents lipopolysaccharide-induced oxidative stress and inflammatory reaction in the rat brain. Neurochem Int. (2017) 108:66-77. doi: 10.1016/j.neuint.2017.02.014

242. Gao J, Wang X, Sun H, Cao Y, Liang S, Wang H, et al. Neuroprotective effects of docosahexaenoic acid on hippocampal cell death and learning and memory impairments in a valproic acid-induced rat autism model. Int J Dev Neurosci. (2016) 49:67-78. doi: 10.1016/j.ijdevneu.2015.11.006

243. Bhandari R, Kuhad A. Neuropsychopharmacotherapeutic efficacy of curcumin in experimental paradigm of autism spectrum disorders. Life Sci. (2015) 141:156-69. doi: 10.1016/j.lfs.2015.09.012

244. Kim J-W, Seung H, Kim KC, Gonzales ELT, Oh HA, Yang SM, et al. Agmatine rescues autistic behaviors in the valproic acidinduced animal model of autism. Neuropharmacology. (2017) 113:71-81. doi: 10.1016/j.neuropharm.2016.09.014

245. Zhang Y, Yang C, Yuan G, Wang Z, Cui W, Li R. Sulindac attenuates valproic acid-induced oxidative stress levels in primary cultured cortical neurons and ameliorates repetitive/stereotypic-like movement disorders in Wistar rats prenatally exposed to valproic acid. Int J Mol Med. (2015) 35:263-70. doi: 10.3892/ijmm.2014.1996

246. Bent S, Lawton B, Warren T, Widjaja F, Dang K, Fahey JW, et al. Identification of urinary metabolites that correlate with clinical improvements in children with autism treated with sulforaphane from broccoli. Mol Autism. (2018) 9:35. doi: 10.1186/s13229-018-0218-4

247. Hendouei F, Sanjari Moghaddam H, Mohammadi MR, Taslimi N, Rezaei F, Akhondzadeh S. Resveratrol as adjunctive therapy in treatment of irritability in children with autism: a double-blind and placebo-controlled randomized trial. J Clin Pharm Ther. (2020) 45:324-34. doi: 10.1111/jcpt.13076

248. Mousavinejad E, Ghaffari MA, Riahi F, Hajmohammadi M, Tiznobeyk Z, Mousavinejad M. Coenzyme Q10 supplementation reduces oxidative stress and decreases antioxidant enzyme activity in children with autism spectrum disorders. Psychiatry Res. (2018) 265:62-9. doi: 10.1016/j.psychres.2018.03.061

249. Nikoo M, Radnia H, Farokhnia M, Mohammadi M-R, Akhondzadeh S. $\mathrm{N}$-acetylcysteine as an adjunctive therapy to risperidone for treatment of irritability in autism: a randomized, double-blind, placebo-controlled clinical trial of efficacy and safety. Clin Neuropharmacol. (2015) 38:117. doi: 10.1097/WNF.0000000000000063

250. Bent S, Hendren RL, Zandi T, Law K, Choi J-E, Widjaja F, et al. Internet-based, randomized, controlled trial of omega- 3 fatty acids for hyperactivity in autism. J Am Acad Child Adolesc Psychiatry. (2014) 53:65866. doi: 10.1016/j.jaac.2014.01.018

251. Yui K, Koshiba M, Nakamura S, Kobayashi Y. Effects of large doses of arachidonic acid added to docosahexaenoic acid on social impairment in individuals with autism spectrum disorders: a double-blind, placebocontrolled, randomized trial. J Clin Psychopharmacol. (2012) 32:2006. doi: 10.1097/JCP.0b013e3182485791

252. Yang J, Fu X, Liao X, Li Y. Nrf2 activators as dietary phytochemicals against oxidative stress, inflammation, and mitochondrial dysfunction in autism spectrum disorders: a systematic review. Front Psychiatry. (2020) 11:561998. doi: 10.3389/fpsyt.2020.561998

253. Liu Y, Yang Z, Du Y, Shi S, Cheng Y. Antioxidant interventions in autism spectrum disorders: a meta-analysis. Prog Neuro Psychopharmacol Biol Psychiatry. (2022) 113:110476. doi: 10.1016/j.pnpbp.2021.110476

254. Hendren RL, James SJ, Widjaja F, Lawton B, Rosenblatt A, Bent S. Randomized, placebo-controlled trial of methyl B12 for children with autism. J Child Adolesc Psychopharmacol. (2016) 26:774-83. doi: 10.1089/cap.2015.0159

255. Lynch R, Diggins EL, Connors SL, Zimmerman AW, Singh K, Liu $\mathrm{H}$, et al. Sulforaphane from broccoli reduces symptoms of autism: a follow-up case series from a randomized double-blind study. Glob Adv Health Med. (2017) 6:2164957X17735826. doi: 10.1177/2164957X177 35826

256. Al-Ayadhi LY, Elamin NE. Camel milk as a potential therapy as an antioxidant in autism spectrum disorder (ASD). Evid Based Complement Alternat Med. (2013) 2013:602834. doi: 10.1155/2013/602834

257. Sadek A, Berk LS, Mainess K, Daher NS. Antioxidants and autism: teachers' perceptions of behavioral changes. Adv Mind Body Med. (2018) 32:12-7.
258. Sporn MB, Liby KT. NRF2 and cancer: the good, the bad and the importance of context. Nat Rev Cancer. (2012) 12:564-71. doi: 10.1038/nrc 3278

259. Itoh $\mathrm{K}$, Chiba $\mathrm{T}$, Takahashi $\mathrm{S}$, Ishii $\mathrm{T}$, Igarashi $\mathrm{K}$, Katoh $\mathrm{Y}$, et al. An Nrf2/small Maf heterodimer mediates the induction of phase II detoxifying enzyme genes through antioxidant response elements. Biochem Biophys Res Commun. (1997) 236:313-22. doi: 10.1006/bbrc.1997.6943

260. Venugopal R, Jaiswal AK. Nrf2 and Nrf1 in association with Jun proteins regulate antioxidant response element-mediated expression and coordinated induction of genes encoding detoxifying enzymes. Oncogene. (1998) 17:3145-56. doi: 10.1038/sj.onc.1202237

261. Kwak M-K, Wakabayashi N, Greenlaw JL, Yamamoto M, Kensler TW. Antioxidants enhance mammalian proteasome expression through the Keap1-Nrf2 signaling pathway. Mol Cell Biol. (2003) 23:87868794. doi: 10.1128/MCB.23.23.8786-8794.2003

262. Liu G-H, Qu J, Shen X. NF-kappaB/p65 antagonizes Nrf2-ARE pathway by depriving CBP from Nrf2 and facilitating recruitment of HDAC3 to MafK. Biochim Biophys Acta. (2008) 1783:713-27. doi: 10.1016/ j.bbamcr.2008.01.002

263. Yu M, Li H, Liu Q, Liu F, Tang L, Li C, et al. Nuclear factor p65 interacts with Keap1 to repress the Nrf2-ARE pathway. Cell Signal. (2011) 23:88392. doi: 10.1016/j.cellsig.2011.01.014

264. Kim J-E, You D-J, Lee C, Ahn C, Seong JY, Hwang J-I. Suppression of NF-kappaB signaling by KEAP1 regulation of IKKbeta activity through autophagic degradation and inhibition of phosphorylation. Cell Signal. (2010) 22:1645-54. doi: 10.1016/ j.cellsig.2010.06.004

265. Shih R-H, Wang C-Y, Yang C-M. NF-kappaB signaling pathways in neurological inflammation: a mini review. Front Mol Neurosci. (2015) 8:77. doi: 10.3389/fnmol.2015.00077

266. Li Y-J, Zhang X, Li Y-M. Antineuroinflammatory therapy: potential treatment for autism spectrum disorder by inhibiting glial activation and restoring synaptic function. CNS Spectr. (2020) 25:493-501. doi: 10.1017/S1092852919001603

267. Holmström KM, Baird L, Zhang Y, Hargreaves I, Chalasani A, Land JM, et al. Nrf2 impacts cellular bioenergetics by controlling substrate availability for mitochondrial respiration. Biol Open. (2013) 2:76170. doi: 10.1242/bio.20134853

268. Kim T-H, Hur E, Kang S-J, Kim J-A, Thapa D, Lee YM, et al. NRF2 blockade suppresses colon tumor angiogenesis by inhibiting hypoxia-induced activation of HIF-1 $\alpha$. Cancer Res. (2011) 71:226075. doi: 10.1158/0008-5472.CAN-10-3007

269. Innamorato NG, Rojo AI, García-Yagüe $A J$, Yamamoto $M$, de Ceballos ML, Cuadrado A. The transcription factor Nrf2 is a therapeutic target against brain inflammation. J Immunol. (2008) 181:680-9. doi: 10.4049/jimmunol.181.1.680

270. Nadeem A, Ahmad SF, Al-Harbi NO, Attia SM, Bakheet SA, Alsanea $\mathrm{S}$, et al. Aggravation of autism-like behavior in BTBR $\mathrm{T}+\mathrm{tf} / \mathrm{J}$ mice by environmental pollutant, di-(2-ethylhexyl) phthalate: role of nuclear factor erythroid 2-related factor 2 and oxidative enzymes in innate immune cells and cerebellum. Int Immunopharmacol. (2021) 91:107323. doi: 10.1016/j.intimp.2020.107323

271. Nadeem A, Ahmad SF, AL-Ayadhi LY, Attia SM, Al-Harbi NO, Alzahrani KS, et al. Differential regulation of $\mathrm{Nrf2}$ is linked to elevated inflammation and nitrative stress in monocytes of children with autism. Psychoneuroendocrinology. (2020) 113:104554. doi: 10.1016/j.psyneuen.2019.104554

272. Schrier MS, Zhang Y, Trivedi MS, Deth RC. Decreased cortical Nrf2 gene expression in autism and its relationship to thiol and cobalamin status. Biochimie. (2022) 192:1-12. doi: 10.1016/ j.biochi.2021.09.006

273. Napoli E, Wong S, Hertz-Picciotto I, Giulivi C. Deficits in bioenergetics and impaired immune response in granulocytes from children with autism. Pediatrics. (2014) 133:e1405-10. doi: 10.1542/ peds.2013-1545

274. Oosterink JE, Naninck EFG, Korosi A, Lucassen PJ, van Goudoever JB, Schierbeek H. Accurate measurement of the essential micronutrients methionine, homocysteine, vitamins B6, B12, B9 and their metabolites 
in plasma, brain and maternal milk of mice using LC/MS ion trap analysis. J Chromatogr B Analyt Technol Biomed Life Sci. (2015) 998-9:10613. doi: 10.1016/j.jchromb.2015.07.008

275. Belardo A, Gevi F, Zolla L. The concomitant lower concentrations of vitamins B6, B9 and B12 may cause methylation deficiency in autistic children. J Nutr Biochem. (2019) 70:38-46. doi: 10.1016/j.jnutbio.2019.04.004

276. Liu S-H, Shi X-J, Fan F-C, Cheng Y. Peripheral blood neurotrophic factor levels in children with autism spectrum disorder: a meta-analysis. Sci Rep. (2021) 11:15. doi: 10.1038/s41598-020-79080-w

277. Dean DD, Agarwal S, Muthuswamy S, Asim A. Brain exosomes as minuscule information hub for autism spectrum disorder. Expert Rev Mol Diagn. (2021) 21:1323-31. doi: 10.1080/14737159.2021.2000395

278. Tonni G, Leoncini S, Signorini C, Ciccoli L, De Felice C. Pathology of perinatal brain damage: background and oxidative stress markers. Arch Gynecol Obstet. (2014) 290:13-20. doi: 10.1007/s00404-014-3208-6

279. Yang Q, Wang G, Zhang F. Role of peripheral immune cells-mediated inflammation on the process of neurodegenerative diseases. Front Immunol. (2020) 11:582825. doi: 10.3389/fimmu.2020.582825
Conflict of Interest: The authors declare that the research was conducted in the absence of any commercial or financial relationships that could be construed as a potential conflict of interest.

Publisher's Note: All claims expressed in this article are solely those of the authors and do not necessarily represent those of their affiliated organizations, or those of the publisher, the editors and the reviewers. Any product that may be evaluated in this article, or claim that may be made by its manufacturer, is not guaranteed or endorsed by the publisher.

Copyright $\odot 2022 \mathrm{Liu}$, Lin, Zhang, Khan, Zhang, Tang, Cao and Shen. This is an open-access article distributed under the terms of the Creative Commons Attribution License (CC BY). The use, distribution or reproduction in other forums is permitted, provided the original author(s) and the copyright owner(s) are credited and that the original publication in this journal is cited, in accordance with accepted academic practice. No use, distribution or reproduction is permitted which does not comply with these terms. 